\section{Otokratisasi dan Populisme Otoriter dalam Rezim Demokrasi: Perbandingan antara India, Hongaria, dan Turki}

\title{
Defbry Margiansyah*
}

Lembaga Ilmu Pengetahuan Indonesia (LIPI)

\begin{abstract}
Abstrak
Kemunduran demokrasi menyurutkan optimisme akan ekspansi demokrasi dunia karena fenomena ini terjadi di rezim-rezim demokrasi mapan. Kemerosotan dari demokrasi ke otokrasi atau otokratisasi dialami oleh India (negara demokrasi terbesar di dunia), Hongaria (negara demokrasi mapan di Uni Eropa), dan Turki(negara demokrasi berpengaruh di dunia Muslim). Meskipun penyebab utama kemunduruan demokrasi terus diperdebatkan, setidaknya para ahli sepakat bahwa adanya kecenderungan otoriter yang didorong pemimpin otokratis dalam mengikis nilainilai demokrasi. Otokratisasi di tiga demokrasi ini terkait erat dengan populisme otoriter yang diadopsi petahana dan sikap antagonistik terhadap demokrasi. Artikel ini mengkomparasikan peranan populisme anti-demokratis di India, Hongaria, dan Turki dalam proses otokratisasi rezim demokrasi di satu dekade terakhir. Proses otokratisasi di mana populisme otoriter berperan signifikan berlangsung melalui apa yang disebut dengan "tahapan otokratisasi", yaitu politisasi kekecewaan rakyat, polarisasi sosial berbasis narasi kultural, pelemahan institusi demokrasi, kontrol informasi alternatif, dan represi oposisi dan pengkritik. Artikel ini berkesimpulan bahwa sebagaimana terlihat dalam kasus India, Hungaria dan Turki, otokratisasi sangat bergantung pada keterampilan petahana memanfaatkan retorika populis demi melegitimasi tindakan otoriter rezim.
\end{abstract}

\section{Kata-kata Kunci}

Otoritarianisme, otokratisasi, kemunduran demokrasi, populisme

\section{Abstract}

Democracy decline undermines optimism for the expansion of world's democracy as it occurred in established democracies.

\footnotetext{
* Penulis untuk korespondensi: 
The decline from democratic to autocratic regime or "autocratization" is being experienced by India (the world's largest democracy), Hungary (the established democracy in the European Union), and Turkey (the influential democracy in the Muslim world). Although they have different views of the main causes of the democracy decline, experts agree that authoritarian tendency driven by autocratic leaders erodes democratic values. The autocratization in the above three democracies is strongly related to "authoritarian populism" adopted by the incumbents and reflected on their antagonistic attitudes towards democracy. This article compares the role of anti-democratic populism in India, Hungary, and Turkey in the process of autocratizing democracies in the last decade. Autocratization in which authoritarian populism plays a significant role occurs through the "autocratization stages" as follows: the politicization of people's disappointment, social polarization based on cultural narratives, weakening of democratic institutions, control of alternative information, and repression of opposition and critics. The article concludes that as seen in the cases of India, Hungary and Turkey, autocratization is highly dependent on the incumbents' skill in exploiting populist rhetoric to legitimize the regime's authoritarian actions.

\section{Key Words}

Authoritarianism, autocratization, democracy decline, populism

\section{Pendahuluan}

Pada abad ke-21, kita menyaksikan bagaimana demokrasi di berbagai belahan dunia mengalami kemunduran. Kekuatan institusi demokrasi dan kebebasan mengalami kemerosotan signifikan di negara-negara mapan. Dalam kurun waktu 1900-2017, V-Dem Institute mencatat 217 peristiwa proses merosotnya demokrasi menuju otokrasi atau otokratisasi di 109 negara dan hanya 69 negara yang belum tersentuh otokratisasi baik di rezim demokrasi (sebanyak 36) ataupun otokrasi (sebanyak 33). Setidaknya 65 persen peristiwa ini terjadi di negara otokrasi dan 30 persen di negara demokrasi. Sebanyak 80 persen otokratisasi di bawah rezim demokratis selalu berujung menjadi negara otokrasi dan hanya 15 persen proses ini dapat dihentikan sebelum tumbangnya demokrasi. Lührmann dan Lindberg (2019) menampilkan tiga gelombang otokratisasi secara empiris dalam kurun waktu tertentu: (1) gelombang pertama 1926-1942 yang cenderung 
menerpa negara demokrasi dan otokrasi; (2) gelombang kedua 1961-1977 yang hanya terjadi pada negara otokrasi elektoral; dan (3) gelombang ketiga 1994-sekarang yang lebih banyak berdampak pada negara demokrasi. Yang menarik adalah studi ini menemukan otokratisasi radikal terjadi di negara-negara demokrasi parlementer terkemuka di kawasannya masingmasing seperti India sebagai negara demokrasi terbesar di dunia, Hongaria sebagai negara demokrasi mapan di Uni Eropa, dan Turki sebagai negara demokrasi berpengaruh di dunia Muslim.

Fenomena kemunduran demokrasi di dunia demikian menyurutkan optimisme akan ekspansi demokrasi di negara-negara non-demokratis. Persoalan ini memicu perhatian banyak kalangan sarjana dan ahli politik dalam mendiagnosis penyebab kemunduran demokrasi dunia ini dari beragam aspek seperti masalah konsolidasi institusi demokrasi (Bermeo 2016; Diamond 2015), resiliensi otoriter (Levitsky dan Way 2015), budaya politik (Foa dan Mounk 2017), struktur sosial dan koalisi politik (Mickey dkk. 2017; Svolik 2020), kompetisi elektoral asimetris (Waldner dan Lust 2018), dan peran internasional (Gleditsch dan Ward 2006). Meskipun penyebab utama kemunduruan demokrasi terus diperdebatkan, setidaknya para ahli sepakat bahwa ada kecenderungan otoriter yang didorong pemimpin otokratis dalam mengikis prinsip, aturan, dan norma demokrasi (Haggard dan Kaufman 2021). Letivsky dan Zinblatt (2018) mengilustrasikan bagaimana demokrasi "mati" di tangan pemimpin otoriter terpilih lewat pemilihan umum dengan melemahkan institusi politik, mengikis norma-norma demokratis, dan merepresi oposisi secara perlahan dan legal, bukan lagi lewat kudeta militer atau revolusi berdarah.

Fenomena merosotnya demokrasi menjadi otokrasi di India, Hongaria, dan Turki terkait erat dengan peran kekuasaan petahana yang tersentralisir dengan sikap antagonistik terhadap demokrasi. India di bawah Perdana Menteri Narendra Modi dan Bharatiya Janata Party (BJP), Hongaria di periode Perdana Menteri Viktor Orbán dan partai Fidesz, dan Turki di bawah pemerintahan Presiden Recep Tayyib Erdogan dan Adalet ve Kalkinma Partisi (AKP) jelas menunjukkan gelagat otoritarianisme tersebut. Terdapat persamaan yang mencolok di antara ketiga pemimpin kuat tersebut dalam menentukan keberhasilan proses otokratisasinya, yaitu populisme sayap-kanan yang bertautan dengan nilai-nilai otoriter dalam menjalankan roda pemerintahannya atau dikenal dengan "populisme otoriter."

Artikel ini bertujuan untuk mengkomparasikan peranan populisme anti-demokratis di India, Hongaria, dan Turki dalam proses otokratisasi rezim demokrasi di satu dekade terakhir. Analisis komparatif ini sangat 
penting untuk mengidentifikasi mekanisme umum yang dimanfaatkan pemimpin populis otoriter dalam membangkitkan kembali otoritarianisme di masing-masing negara. Dengan begitu, studi ini dapat mengungkapkan "wajah baru" politik otoriter yang masih kokoh di zaman demokrasi kontemporer.

Dalam menjelaskan masalah di atas, artikel ini selanjutnya dibagi atas empat bagian. Bagian pertama fokus dalam menjelaskan keterkaitan antara otoritarianisme, populisme, dan otokratisasi sebagai kerangka konseptual dalam analisis utama. Bagian kedua mendeskripsikan proses otokratisasi global secara umum dan mengelaborasi aspek-aspek krusial yang menyebabkan runtuhnya rezim demokrasi di tiga negara. Pemetaan masalah otokratisasi secara spesifik akan menghantarkan kita pada bagian ketiga yang mendeteksi berbagai mekanisme bangkitnya otoriteritarianusme dengan membandingkan modus operandi populisme otoriter di masingmasing negara dalam melemahkan sistem demokrasi secara substansial. Analisis ini diikuti dengan kesimpulan di bagian akhir yang merefleksikan otokratisasi lewat populisme anti-demokrasi dan menyoroti potensi kebangkitannya di rezim demokrasi yang belum terkonsolidasi dengan kuat.

\section{Keterkaitan Otoritarianisme, Populisme, dan Otokratisasi: Kerangka Analisis}

Dalam memahami keterkaitan otoritarianisme, populisme, dan otokratisasi secara konseptual, kita perlu mendefinisikan otoritarianisme sesuai dengan konteks dinamika politik abad ke-21. Berbagai literatur memahami otoritarianisme dalam dua makna, yaitu tipe rezim dan tipe psikologi sosial. Otoritarianisme sebagai tipe rezim merujuk pada seperangkat aturan, kelembagaan negara, dan pengambilan keputusan yang ditentukan oleh keinginan penguasa, baik itu rezim militer, partai tunggal, personalis, ataupun campuran, dengan cara-cara non-demokratis (Frantz 2018; Geddes 1999). Sementara itu, otoritarianisme sebagai tipe psikologi masyarakat menekankan pada sikap individu atau pemilih yang taat pada penguasa atau politisi otokratis berdasarkan kesamaan nilai dan kepercayaan tanpa intimidasi atau teror (Norris dan Inglehart 2019). Dua definisi ini menunjukkan keterbatasannya karena berasumsi bahwa otoritarianisme merupakan efek ketiadaan demokrasi seperti absennya pemilihan umum kompetitif, hak pilih universal, kebebasan sipil, dan sumber informasi alternatif (Dahl 1971). 
Keterbatasan ini akan sulit memahami otoritarianisme dalam dua hal: praktik-praktik otoriter dalam rezim demokrasi oleh pemimpin yang terpilih secara demokratis dan perbedaan perilaku politisi otoriter saat kampanye dan saat berkuasa. Walaupun begitu, para sarjana politik telah mengingatkan karakter khas otoritarianisme yang terus relevan dengan konteks demokrasi kontemporer di mana pembagian kekuasaan dan prosedur demokrasi telah terlembaga. Adapun ciri khas tersebut meliputi (1) stabilitas dan keamanan merupakan prioritas utama, (2) kedisiplinan terhadap pemimpin dan kearifan nilai-nilai tradisional sebagai pelindung kehidupan, (3) tingkat ideologi dan pluralitas sosial yang tinggi dianggap abnormal dalam politik, dan (4) depolitisasi dan demobilisasi rakyat dibutuhkan untuk mencegah perubahan sistemik pada kekuasaan penguasa yang tersentralisir (Babones 2018; Cerutti 2017; Ezrow dan Frantz 2011; Linz 1964; Norris dan Inglehart 2019).

Untuk memahami otoritarianisme kekinian berdasarkan karakter khas di atas, artikel ini fokus pada esensi dari proses demokrasi, yaitu akuntantabilitas pemerintahan dari pemimpin terhadap rakyatnya. Fokus ini lebih relevan untuk memahami politik otoriter secara praktis. Studi ini mengartikan otoritarianisme sebagai "pola tindakan yang menyabotase akuntabilitas terhadap rakyat, yang mana kontrol aktor politik utama atau perwakilannya dilakukan melalui kerahasiaan, disinformasi, dan pembungkaman suara" (Glasius 2018:524). Definisi ini diadopsi untuk memahami lebih dalam pelemahaman demokrasi lewat praktik otoriter nir-integritas, intransparan, dan manipulatif oleh aktor otoriter, di mana diskursus demokrasi dan otokrasi dipadupadankan dalam politik kekuasaannya.

Di samping definisi otoritarianisme, artikel ini juga mendefinisikan iliberalisme karena pada prakteknya kedua gagasan ini dieksploitasi secara bersamaan untuk melemahkan proses demokrasi. Illiberalisme cenderung dipraktikkan untuk membahayakan hak asasi manusia (HAM) dan kebebasan, terutama kelompok penentang seperti oposisi, organisasi masyarakat sipil (civil society organizations), dan pengkritik lainnya. Karena itu, illiberalisme lebih diartikan sebagai "pola tindakan pelanggaran atas otonomi dan martabat individu, yang melekat pada suatu konteks sosial politik yang terorganisir". Kedua ide ini sangat terkait karena selalu dieksploitasi oleh penguasa otoriter sebagai strategi untuk memanipulasi institusi demokrasi dan legitimasi tindakan represif rezim kepada publik demi meraih atau mempertahankan status quo (Glasius 2018:529-530). 
Definisi otoritarianisme dan illiberalisme di atas sangat relevan untuk memahami tendensi anti-demokratis yang melekat dalam rezim demokrasi, yakni populisme. Menurut Cas Mudde (2004:562), populisme pada dasarnya merupakan ideologi "cair" (thin-centered ideology) yang tidak menawarkan sistem sosial-politik ideal ataupun kebijakan spesifik, melainkan gagasan tentang "masyarakat terdikotomi antara 'rakyat murni' dan 'elit korup' yang saling bertentangan, dan politik seharusnya menjadi ekspresi atas kehendak umum rakyat. Gagasan populisme selalu termanifestasikan dalam berbagai retorika, yaitu (1) mempertanyakan "legitimasi" dari otoritas elit penguasa sebagai "kehendak rakyat"; (2) mengakui "suara rakyat biasa" sebagai satu-satunya sumber legitimasi yang superior, otentik, dan bermoral dalam rezim demokrasi; (3) berusaha menghilangkan kepercayaan publik terhadap keabsahan wewenang perwakilan terpilih secara demokratis (Norris dan Inglehart 2019). Karena itu, gagasan populisme bersifat fleksibel dan tidak dapat terwujud dengan sendirinya tetapi membutuhkan manifestasi yang berpadu dengan gagasan lain dalam banyak fenomena (Mudde dan Kaltwasser 2017).

Fleksibilitas populisme pada realitanya memang selalu berkelindan dengan ide dan praktik otoriter dan illiberal atau anti-demokrasi lain (Margiansyah 2019). Tendensi otoriter yang diselubungkan dalam narasinarasi populis yang mempolitisasi problem sosial-ekonomi dan sosialkultural sebagai ancaman eksistensial seperti ketimpangan ekonomi, ketidakadilan sosial, pengikisan nilai tradisional, dan identitas nasional yang melemah (Inglehart dan Norris 2016)the cultural backlash thesis suggests that support can be explained as a retro reaction by once-predominant sectors of the population to progressive value change. To consider these arguments, Part I develops the conceptual and theoretical framework. Part II of the study uses the 2014 Chapel Hill Expert Survey (CHES. Retorika berbasis ketakutan itu dimanfaatkan untuk memobilisasi dukungan massa terhadap diskursus atau kebijakan bersifat us-versus-them, proteksionis, dan konservatif terhadap urusan privat yang progresif. Manuver politik demikian pada akhirnya akan menghasilkan populisme yang teguh bersikap anti-kemapanan, anti-liberal, dan mengedeankan pemerintahan kuat dalam menjaga menjaga ketertiban (order) dan keamanan (security) negara, walaupun substansi demokrasi, supremasi hukum (rule of law), dan kebebasan sipil harus dikorbankan (Norris dan Inglehart 2019).

Tendensi populis dalam otoritarianisme semakin mempertegas hubungan antagonistik antara populisme dan demokrasi. Bagi beberapa sarjana, populisme memiliki peran meningkatkan kualitas demokrasi dan partisipasi politik dengan memberi kelompok sosial anti-mainstream 
kemampuan untuk mengoreksi inklusivitas politik melalui checkand-balance dan legitimasi populer. Beberapa analis lain melihat kecenderungan kuat kelompok populis untuk mempraktikkan politik antidemokratis kendati menekankan kedaulatan rakyat, prinsip demokrasi (Gidron dan Bonikowski 2013). Ahli-ahli lainnya justru melihat populisme bertentangan dengan demokrasi karena sifat anti-pluralismenya yang mengklaim diri sebagai satu-satunya perwakilan rakyat yang sah, dan rival politik dianggap sebagai musuh rakyat, korup, dan imoral (Abts dan Rummens 2007; Müller 2016).

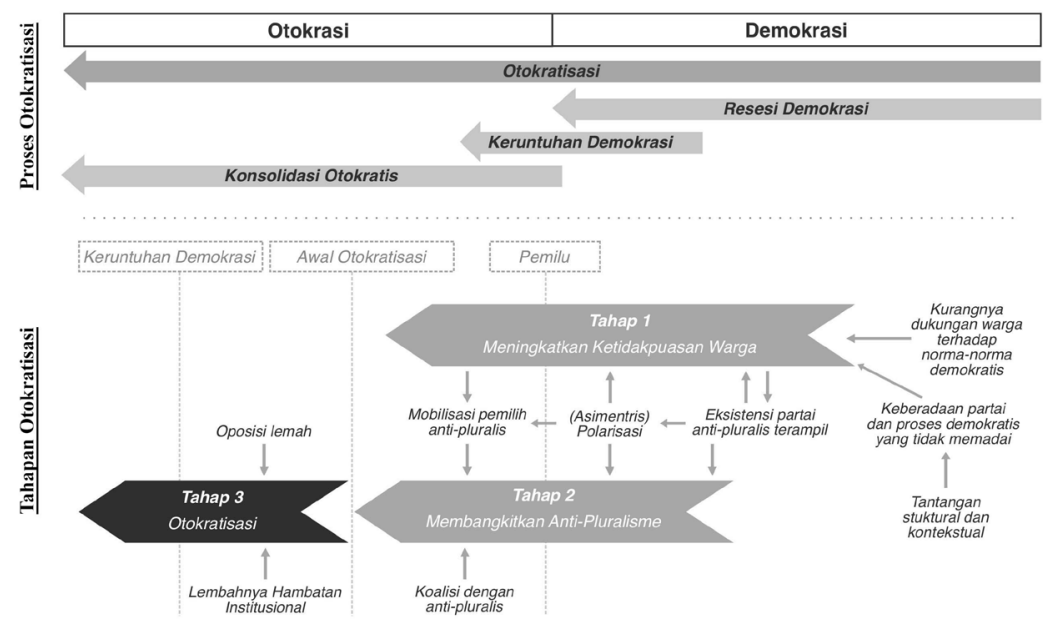

Gambar 1

Proses Otokratisasi dan Tahapannya (Lührmann 2021; Lührmann dan Lindberg 2019).

Relasi populisme-demokrasi yang antagonistik menjadi titik tolak untuk mengelaborasi intensifikasi otokratisasi di negara-negara demokrasi. Otokratisasi yang didefinisikan sebagai proses perubahan substasial dari rezim demokrasi menuju otokrasi, terutama hilangnya kriteria dasar institusi elektoral dan demokrasi (Cassani dan Tomini 2019; Lührmann dan Lindberg 2019). Proses ini tercipta dari transformasi institusi-institusi yang mengelola kontentasi, partisipasi politik, dan batas-batas wewenang pemerintahan eksekutif baik secara formal maupun informal. Pada setiap tahapan otokratisasi, terdapat tiga proses demokratisasi terbalik dengan tingkat dan kualitas berbeda (Gambar 1.), yaitu (1) resesi demokrasi (democratic recession) yang menggambarkan otokratisasi pada rezim demokrasi; 2) keruntuhan demokrasi (democratic breakdown) yang menunjukkan tahap tumbangnya pemerintahan demokrasi menuju 
otokrasi; dan 3) konsolidasi otokratis (autocratic consolidation) yang menandakan hilangnya sifat-sifat demokratis pada rezim otoriter secara gradual (Lührmann dan Lindberg 2019).

Dalam analisis otokratisasi di berbagai negara, Anna Lührmann (2021:1017) menemukan kesamaan pola dari tahapan proses tersebut, yaitu "pemimpin petahana yang berkuasa lewat pemilu demokratis, tetapi melakukan pelemahan substantif terhadap institusi-institusi demokrasi", secara bertahap dalam beberapa tahun. Pola umum otokratisasi terjadi dalam tiga tahapan seperti pada Gambar 1. Tahap pertama adalah "meningkatnya ketidakpuasan warga" pada kinerja partai dan institusi demokrasi dalam menangani problem struktural dan kontekstual, ketidakpastian ekonomi, disfungsi pemerintahan, dan perubahan budaya yang berdampak negatif pada realitas sosial. Ketidakpuasan yang umumnya dimulai pada momentum pemilu ini dipolitisasi oleh pemimpin anti-pluralis untuk mengurangi kepercayaan dan melemahkan komitmen publik terhadap norma-norma, lembaga, dan aktor demokratis. Tahap kedua terkait erat dengan ketidakpuasan warga pada demokrasi yang menjadi peluang bagi "pemimpin anti-pluralis naik ke tampuk kekuasaan" dengan memanfaatkan keterampilan politiknya untuk mengeksploitasi kekecewaan publik demi melegitimasi retorika polarisasi antara "rakyat tertindas" melawan "elit penguasa korup". Taktik ini merupakan upaya memobilisasi potensi dukungan suara dan meningkatkan modal politik kelompok anti-pluralis dalam membangun koalisi dengan kelompok dominan lain untuk memastikan tempat dalam kekuasaan. Tahap ketiga merupakan puncak otokratisasi di mana "otokrator' merombak institusi demokrasi" secara sewewenang-wenang untuk menumbangkan resilisensi sistem demokrasi, mekanisme akuntabilitas, dan melemahkan eksistensi oposisi. Hal ini dilakukan dalam rangka melucuti berbagai aturan hukum yang dapat menghambat eksekutif berkuasa penuh.

Dari penjelasan ini, kita dapat menemukan basis konseptual dari hubungan erat antara otoritarianisme, populisme, dan otokratisasi dalam fenomena kemunduran demokrasi global. Keterkaitan gagasan ini sangat relevan untuk menganalisis lanskap politik demokratis dalam menghadapi intensifikasi politik otoriter yang sangat dinamis dan inovatif, termasuk penyesuaian gagasan dan pengaruh anti-demokratis masa lalu dalam rezim demokrasi masa kini. Dengan demikian, kerangka ini penting sebagai panduan bagi proses analisis untuk mengindentifikasi mekanisme kerja otoritarianisme baru dalam rezim-rezim demokrasi dengan latar belakang geografis dan sosio-kulutral berbeda. 


\section{Kemerosotan Demokrasi menuju Otokrasi: Kasus Hongaria, India, dan Turki}

Fenomena kemerosotan demokrasi pasca Perang Dingin sangat menarik perhatian para ahli karena rezim-rezim demokrasi mapan turut mengalami kemunduran (Boese dkk. 2021). Pada tahun 2019, tren pembalikan demokrasi semakin intensif di 26 negara, di mana 8 negara demokrasi mengalami kemunduran kualitas demokrasi secara drastis. Setidaknya terdapat pola umum yang dieksploitasi politisi anti-demokratis dalam proses otokratisasi, yaitu represi media dan masyarakat sipil, diikuti dengan polarisasi masyarakat dan mobilisasi dukungan terhadap otoriter, dan terakhir pemerintah inkamben berusaha melemahkan substansi dan ini dari institusi demokrasi, lembaga yudisial dan pemilu kompetitif. Pola ini dipilih secara strategis dan gradual, umumnya oleh pemimpin petahana, agar dapat menekan potensi kerugian material, konstitusional, dan politik bagi legitimasi pemimpin otokratis dalam proses pelemahan demokrasi (Maerz dkk. 2020).

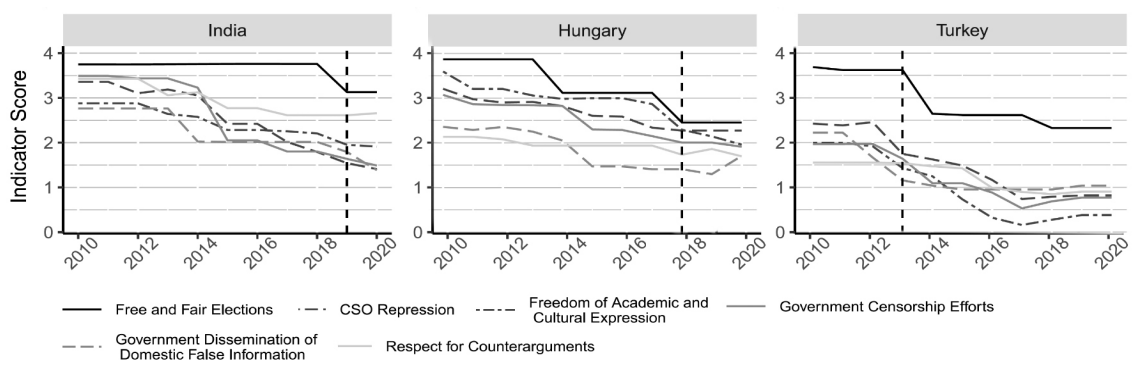

Gambar 2

Otokratisasi di India, Hungari dan Turki Periode 2010-2020 (diadopsi dari Hellmeier dkk. 2021)

Pada tahun 2020, tren otokratisasi terus berlanjut di 25 negara dengan besaran populasi setara 38 persen penduduk dunia, sedangkan demokratisasi hanya terjadi di 16 negara. Keberlanjutan tren kemunduran ini tidak lepas dari pandemi COVID-19 dan tindakan restriktif negara terhadap kebebasan berkumpul dan mobilisasi massa, meskipun faktor utama otokratisasi adalah intensifikasi ancaman terhadap kebebasan berekspresi oleh pemerintah berkuasa. Keterlibatan pemimpin kuat dan karismatik dalam proses otokratisasi membuat beberapa negara demokrasi mapan berada dalam ambang transisi menuju pendalaman otoritarianisme. Rilis data 
Liberal Democracies Index (LDI) dari V-Dem Institute, indikator penilaian tingkat demokrasi suatu negara pada skala nilai terendah " 0.0 " dan tertinggi "1.0" poin, menunjukkan tiga negara yang mengalami penurunan kualitas demokrasi secara radikal dalam dalam satu dekade terakhir (2010-2020), yaitu India, Hongaria, dan Turki. Ketiga negara ini menyandang status "demokrasi elektoral" di tahun 2010 tetapi menjadi "otokrasi elektoral" di 2020, di mana seluruh kemunduran radikal tersebut cenderung banyak disebabkan oleh pelanggaran terhadap kebebasan berekspresi, media, dan masyarakat sipil oleh pemerintah inkamben (Hellmeier dkk. 2021).

Tingkat demokrasi India mengalami kemerosotan signifikan dari nilai 0.57 di 2013 ke 0.34 di 2020. Sejak pemerintahan Narendra Modi dan kemenangan besar BJP di pemilu 2014 dengan mempromosikan agenda nasionalis-Hindu, penurunan drastis demokrasi India menjadi otokrasi elektoral mengindikasikan terdapat disfungsi pilar-pilar demokrasi formal atau informal di negara demokrasi berpopulasi terbesar di dunia ini. Ketidakberfungsian tersebut utamanya mengacu pada indikator penilaian yang menandai pergeseran tindakan koersif pemerintah dalam penyensoran media, represi organisasi masyarakat sipil, dan pelemahan otonomi lembaga pengelola pemilu, meskipun pemilu kompetitif masih dinilai berlangsung stabil (Gambar 2). Faktor-faktor utama yang terkait erat dengan kondisi kebebasan berekspresi, media, dan kebebasan sipil ini menjadi kemerosotan yang paling mencolok dalam pemerintahan India di era BJP. Rezim Modi memanfaatkan aturan hukum untuk membungkam pengkritik dan jurnalis independen yang kritis terhadap kebijakan pemerintah, tetapi pasif menangani kasus-kasus diskriminasi dan kekerasan yang memakan korban nyawa dari minoritas Muslim dan Dalit, khususnya yang melibatkan simpatisan BJP dan Hindu nasionalis (Hellmeier dkk.)

Kondisi kemunduran demokrasi serupa juga telah dialami Hongaria di mana nilai LDI-nya terus mengalami kemunduran bertahap dari 0.68 di 2010 ke 0.37 di 2020, khususnya sejak Viktor Orbán dan partai Fidesz berkuasa. Regresi sebesar minus (-)0.32 poin dalam kurun waktu 10 tahun yang dialami Hongaria menjadi tren otokratisasi paling mencolok karena pada dekade sebelumnya negara ini masih dikategorikan sebagai rezim "demokrasi liberal", dengan skor 0.76 poin dalam indeks yang sama (Maerz dkk., 2020). Gambar 2 menunjukkan bahwa hilangnya status demokrasi elektoral bagi Hongaria di 2018 merupakan konsekuensi atas terjadinya rentetan peristiwa yang melibatkan tindakan anti-demokratis negara baik dalam kebebasan sipil, media dan akademik, maupun dalam kinerja pemilu bebasnya. Indikator tersebut diawali dengan penerapan beberapa produk legislasi baru tentang media yang membatasi kebebasan 
pers dan independensi media massa di bawah kontrol ketat negara dengan dibentuknya otoritas media nasional yang berwenang untuk mengintervensi konten detail dari laporan media pers, termasuk larangan pemberitaan isuisu terkait aktivisme lingkungan dan HAM yang sensitif bagi petahana (Bayer 2020).

Regresi demokrasi yang dialami Turki merupakan salah satu kasus konsistensi otokratisasi yang terjadi lebih dari satu dekade. Pada tahun 2020, tingkat demokrasi Turki berada di level terendah, berada di nilai 0.11 berdasarkan LDI, dan skor ini turun sebesar 0.29 dari nilai 0.40 di tahun 2010 ketika statusnya masih sebagai rezim "demokrasi elektoral". Penurunan status sejak 2014 tidak lepas dari menyempitnya ruang-ruang demokratis oleh penggunaan kekerasan aparatur negara dalam merespon serangkaian protes damai warga seperti saat "Gezi Park Uprising" dan "Pemilu 7 Juli 2015", terhadap penguatan dominasi politik Recep Tayyib Erdogan dan manipulasi politiknya. Indikator penilaian di Gambar 2. merefleksikan adanya intensifikasi tindakan represif rezim Erdogan terhadap seluruh oposisi sosial dan politik baik penangkapan jurnalis, politisi oposisi, dan akademisi, selain pembredelan media-media kritis, pelemahan aktivitas aktivisme sipil, kebebasan berekspresi, dan melemahkan pemilihan umum bebas dan adil.

Serangkaian temuan empiris tentang otokratisasi di tiga negara demokrasi ini mengkonfirmasi bahwa politisi otoriter masa kini lebih tertarik menggunakan taktik-taktik bersifat legal dan gradual dalam mengikis substansi demokrasi (Lührmann dan Lindberg 2019). Dalam otokratisasi rezim demokrasi, proses pengikisan demokrasi ini dimulai dengan pengejawantahan hasrat berkuasa para autokrat lewat mekanisme demokrasi prosedural, dikarenakan dua hal. Pertama, pemilihan umum akan memudahkan politisi otokratis menggalang legitimasi publik secara damai dengan meminimalisasi chaos dan korban nyawa dalam pergantian rezim. Kedua, pemilihan umum multipartai telah dianggap sebagai norma global dan mekanisme paling absah dalam peralihan kekuasaan politik, termasuk negara non-demokratis sekalipun (Levitsky dan Way 2020). Otokratisasi yang dimulai dari penghapusan sistem pemilihan umum multipartai akan terlalu beresiko bagi legitimasi politisi otoriter. Karena itu, upaya paling realistis dan efektif dalam otokratisasi adalah "inovasi otoriter", ${ }^{1}$ yaitu penggunaan taktik mutakhir untuk memanipulasi institusi demokrasi dan memobilisasi konsensus publik terhadap agenda-agenda anti-demokrasi negara (Curato dan Fossati 2020), termasuk meniru dan

1 Inovasi otoriter termanifestasikan dalam lima bentuk teknik penguasaan (lewat beberapa cara): inovasi informasi (gugatan defamasi), legal (tindakan anti-masyarakat sipil), politis (manipulasi citra akuntabel atau penghinaan terhadap kepatuhan hak asasi manusia), reputasi (konsultan atau firma humas, lembaga pemikir, atau 'zombie monitor' dalam pemilu), dan teknologis (invansi pasukan troll internet atau 'buzzer' yang terinstitusionalisasi). Inovasi-inovasi otoriter ini menyasar empat aktor utama seperti warganegara, aktivis sipil, anggota posisi, dan para pembuat keputusan dari luar negeri secara sistematis (Morgenbesser 2020). 
mengadaptasi politik otoriter dengan norma dan praktik demokratis dengan beragam bentuk teknik penguasaan (Morgenbesser 2020).

\section{Mekanisme Kebangkitan Otoritarianisme Baru: Perbandingan Tiga Populisme Otoriter}

Kajian otokratisasi di tiga negara demokrasi di atas memberikan gambaran bagaimana politisi otoriter bangkit dengan menyabotase substansi demokrasi dalam meraih relevansi politik dan dukungan mayoritas warganegara. Perebutan kekuasaan melalui metode illiberal dan brutal telah dianggap usang dan cenderung menghasilkan resistensi sosial lebih besar yang terbukti di 34 negara pada tahun 2019 yang sukses menekan dan menggulingkan petahana otokratis seperti di Tunisia, Sudan, Aljazair, dan Armenia (Maerz dkk. 2020). Kondisi ini memaksa politisi otokratis beradaptasi dan berinovasi lewat respon rasional dan kreatif (Margiansyah 2020) lewat populisme otoriter dalam mempertahankan relevansi politiknya.

Dalam otokratisasi di India, Hongaria, dan Turki, kesuksesan perubahan tiga rezim demokrasi menuju otokrasi elektoral ini tidak lepas dari efektifitas populisme anti-demokrasi yang dieksploitasi oleh masingmasing petahana. Narendra Modi, Viktor Orbán, dan Recep Tayyip Erdoğan merupakan figur-figur populis generasi baru yang piawai dalam memainkan narasi "kerakyatan" dan "anti-elitisme" dalam menggalang "legitimasi" rakyat dan dukungan massa terhadap agenda otoriter dan illiberal dalam pemerintahannya (Norris dan Inglehart 2019). Ketiga pemimpin populis ini menafsirkan demokrasi dalam kerangka mayoritarianisme yang menekankan hak mayoritas daripada konstitusionalisme atau supremasi hukum, dan kebebasan sipil (Pappas 2014).

Pandangan Modi yang direpresentasikan oleh BJP mengartikan demokrasi, utamanya prinsip checks and balances, deliberasi dan hak minoritas, sebagai penghalang bagi perwujudan kehendak rakyat (McDonnell dan Cabrera 2019). Orbán memahami demokrasi tidak harus mengikuti model liberal yang diadopsi Barat, terutama multikulturalisme dan pro-imigrasi, dalam membentuk negara non-liberal, tetapi mendukung demokrasi alternatif, yaitu "demokrasi Kristen" yang mengedepankan budaya, nilai, keluarga Kristen, dan rakyat Hongaria (Plattner 2019). Interpretasi demokrasi Erdoğan tercermin dari identitas partai AKP yang menekankan keinginan mayoritas, berbasis konservatisme Islam, dengan mengedepankan penghormatan pada preferensi, norma, dan nilai "rakyat" Turki, khususnya suara silent mass yang tertindas oleh rezim otoritarianisme sekuler (Gumuscu 2013). 
Berkaitan dengan itu, artikel ini mengidentifikasi setidaknya ada lima mekanisme yang harus dipahami dalam menjelaskan proses otokratisasi di mana populisme anti-demokrasi berperan signifikan. Merujuk pada "tahapan otokratisasi" sebelumnya, mekanisme dimulai dari politisasi ketidakpuasan, polarisasi sosial berbasis narasi kultural, pelemahan institusi demokrasi, kontrol informasi alternatif, dan represi oposisi dan pengkritik. Mekanisme ini dapat terjadi secara simultan atau linier tergantung pada konteks sosial politik.

\section{Politisasi Ketidakpuasan untuk Memenangkan Pemilu}

Mekanisme elektoral menjadi jalur paling potensial dalam memfasilitasi kebangkitan autokrat populis karena memberikan kesempatan besar untuk memenangkan kompetisi melalui mobilisasi massa dengan narasi anti-pluralis, sentimental, dan provokatif. Proses elektoral semakin menguntungkan agenda populis otoriter ketika negara sedang mengalami gejolak dan instabilitas ekonomi, sosio-kultural, dan struktural seperti krisis, ketidakadilan, ketimpangan ekonomi, dan kecemasan kultural (Lührmann 2021). Problem struktural dan sosial ekonomi yang berkepanjangan selalu menjadi target politisasi populis untuk mengonfirmasi inkapabilitas elit-elit pemerintahan dengan retorika antagonistik rakyat versus elit korup. Narasi populis yang digaungkan tidak lain untuk mengkonversi kekecewaan dan ketidakpuasan massa menjadi suara pada pemilu (Moffitt 2016).

Mekanisme politisasi kekecewaan terbukti berhasil menghantarkan partai BJP dan Narendra Modi pada kesuksesan elektoral pada tahun 2014 dan mengakhiri 10 kekuasaan Partai Kongres. Kampanye politik partai BJP berakar kuat dari ideologi Hindutva atau nasionalisme Hindu dan dikombinasikan dengan developmentalisme neoliberal untuk membedakan diri dari corak pemerintahan Partai Kongres yang kebijakannya dianggap gagal untuk menangangi krisis keamanan, ekonomi, dan skandal korupsi. Saat kampanye Modi menampilkan diri sebagai pemimpin penyelamat bangsa dan pelayan rakyat, dan mengklaim sebagai "rakyat biasa" yang bertujuan melawan korupsi dari dalam sistem. Narasi ini menjadi fondasi branding politiknya dalam menyerang dan mendeskreditkan Partai Kongres sebagai elit korup yang akomodatif terhadap imigran Muslim ilegal yang telah mencuri pekerjaan orang India. Narasi populis Modi tersebut menyasar pemilih dari kaum Hindu ekonomi marjinal, kasta tinggi, kelas menangah-atas, kalangan konservatif sosial, dan ekonomi Kanan. Hasilnya, BJP berhasil mengunguli Partai Kongres dengan memenangi mayoritas kursi di the lower house "Lok Sabha", semacam dewan perwakilan rakyat, 
dengan perolehan 282 kursi dari total 545 (Chacko 2018; McDonnell dan Cabrera 2019)2018; McDonnell \& Cabrera, 2019.

Sama halnya dengan kasus Hongaria, politisasi krisis keuangan dan arus migrasi dan pengungsi berhasil mengantarkan Fidesz dan Viktor Orbán ke tampuk kekuasaan untuk kedua kalinya setelah periode 1998-2002. Kemenangan Fidesz di pemilihan umum 2010 tidak lepas dari kegagalan model pembangunan neoliberal yang diadopsi pemerintahan petahana dari Partai Sosialis (MSZP) dalam mengatasi krisis ekonomi Hongaria. Pada periode ini, Hongaria mengalami defisit anggaran 9 persen dari PNB, defisit terbesar di antara anggota Uni Eropa (UE). Penurunan investasi asing, pendapatan pajak, rerata pertumbuhan, dan tingkat kesejahteraan secara bersamaan diperparah dengan skandal korupsi merusak kredibilitas MSZP. Ketergantungan Partai Sosialis pada institusi internasional (neoliberal) seperti IMF dan UE membuat gagasan nasionalisme Orbán semakin relevan dalam membuktikan bahaya laten liberalisme bagi Hongaria yang disusupi oleh "agen elit asing". Provokasi kekecewaan warga ini terbukti ampuh membawa Fidesz pada kemenangan di pemilihan umum 2010 dengan 52,9 persen (42.0 persen di 2006) suara dan unggul telak dari MSZP yang hanya mendapat 20,9 persen (43,2 persen di 2006). Dengan kemenangan ini, Fidesz dapat membentuk pemerintahan satu partai dan menguasai dua pertiga mayoritas kursi di parlemen atau 262 dari 378 kursi (Becker 2010; Miklós dan Simons 2021).

Berbeda dari Modi dan Orbán yang beraksi dalam demokrasi terkonsolidasi, Recep Tayyip Erdoğan dan AKP di Turki menggunakan mekanisme ini dalam konteks "tutelary democracy" di mana politisasi kekecewaan digunakan sebagai strategi elektoral untuk melawan "veto players" militer, peradilan, dan kelompok Kemalis yang lebih berkuasa di seluruh institusi negara daripada pejabat terpilih. Pada awal 2000-an, partai Islamis AKP pimpinan Erdoğan kembali muncul ke panggung politik Turki setelah rangkaian pembubaran oleh kudeta militer dan Mahkamah Konstitusi dengan klaim diri sebagai "demokrat konservatif" (Islamis moderat) dengan agenda-agenda programatif yang bertujuan reformasi sistem demokrasi yang berorientasi pada supremasi sipil, ekonomi neoliberal, dan hubungan luar negeri yang pro-Uni Eropa dan Amerika Serikat. Visi politik reformis dan demokratis tersebut semakin meningkatkan kedibilitas AKP sebagai partai anti-kemapanan dan Erdoğan sebagai pemimpin luar elit. Reputasi ini dipandang sebagai representasi politik kelompok periferal yang termarjinalkan oleh kekuasaan otoriter Kemalisme seperti kaum petani, pedagang dan pengrajin kecil, liberal 
yang kecewa, Muslim dan non-Muslim, etnis minoritas, dan komunitas politik lainnya (Castaldo 2018).

Bersamaan dengan itu, pemerintah koalisi partai sekuler Kemalis menunjukkan kegagalan dan inkapabilitasnya dalam menangani tingginya inflasi dan skandal korupsi dan mencegah kejatuhan sektor finansial dan resesi ekonomi. Krisis ekonomi dan buruknya kinerja petahana berdampak pada hilangnya kepercayaan publik terhadap partai-partai tradisional sekuler, sedangkan narasi populis anti-kemapanan Erdoğan lebih menjanjikan untuk mewakili aspirasi rakyat biasa dan kondusif terhadap identitas keagamaan dan etnis dari sebagian besar penduduk Turki. Hasilnya, politisasi kekecewaan warga terhadap situasi ekonomi dan pemerintahan yang buruk terbukti efektif memenangkan AKP di pemilihan umum 2002 dengan perolehan sekitar 34 persen suara atau dua pertiga mayoritas kursi di pemilihan umum 2002, selisih lebih 15 persen dari Cumhuriyet Halk Partisi (CHP), kompetitor sekuler (Gumuscu 2013).

\section{Polarisasi Sosial Berbasis Narasi Kultural}

Efektivitas politisasi kekecewaan warga sangat berkelindan dengan polarisasi sosial dalam wilayah konstituen. Kondisi ini mendorong politisi populis untuk meningkatkan strategi politik yang membakar sentimen masyarakat berdasarkan kedekatan identitas kolektif, yang umumnya menyasar psikologi sosial kelompok mayoritas. Strategi divisif ini bertujuan untuk mengamankan loyalitas dari sebagaian besar penduduk dan legitimasi "rakyat" terhadap kuasa populis otoriter. Melalui interpretasi "demokrasi mayoritarianisme", populis otoriter mengunakan politik ketakutan, kebencian, dan permusuhan terhadap "musuh rakyat" yang menunjuk kepada elit-elit mapan arus utama, minoritas, dan entitas asing (Canovan 1981), dan selalu mengklaim mewakili dan melindungi kedaulatan "rakyat" (mayoritas) dan "negara" dari "elit korup" dan "kelompok liyan" (the others). Diskursus etno-nasionalis atau etnos-relijius merupakan fitur penting dari strategi populis otoriter untuk membentuk persepsi politik berbasis aspirasi mayoritas atau nostalgia masa lalu, dengan menempatkan autokrat populis sebagai simbol pemimpin kuat masa kini. Persepsi politik ini bekerja untuk memanipulasi persepsi dan mengokupasi ruang publik dalam memolarisasi masyarakat bukan berdasarkan rasional atau komitmen ideologis, tetapi emosional atau loyalitas partisan terhadap populis otoriter (Rogenhofer dan Panievsky 2020; Snyder 2017).

Di India, Narendra Modi dengan BJP mengklaim diri sebagai pemimpin kuat representasi rakyat biasa yang tumbuh dari keluarga miskin 
di luar Delhi dan terisolasi dari kelas elit. Makna "rakyat" ini merujuk pada orang-orang Hindu dan India yang patriotis dan identifikasi ini untuk membedakan mana pihak rakyat, pihak elit, dan "kelompok liyan" dalam pertarungan politik. Dalam pandangan BJP, kalangan "elit-elit imoral" adalah elemen Partai Kongres, komunis, liberalis, dan jurnalis kritis, sedangkan "liyan" adalah Muslim, anti-nasional, dan Dalit, kaum di luar kasta yang menjadi penghalang pencapaian kehendak mayoritas "rakyat" dan ancaman bagi negara India (McDonnell dan Cabrera 2019).

Wacana etno-relijius yang sangat kental dalam definisi "rakyat" dimaksudkan untuk mempertegas pembedaan politik antara pendukung dan penentang agenda Hindutva, serta menyamakan identitas Hindu dengan identitas nasional. Konsepsi mayoritarianisme ini dimanfaatkan untuk meningkatkan kredensial Modi sebagai pemimpin kuat bagi "rakyat" dan memperdalam polarisasi sosial, lewat mobilisasi kebencian terhadap Muslim, Khasmir, Pakistan, dan kaum "anti-nasional" lain. Akibatnya, percampuran nasionalis-patriotis dan Hindu dalam populisme Modi memberikan sumber legitimasi besar bagi agenda nasionalisme Hindu dan keberlanjutan kekuasaannya, terutama dari pendukung yang identitas dan pandangannya selaras dengan populisme Hindu (Rogenhofer dan Panievsky 2020).

Dalam konteks Hongaria, diskursus etno-nasionalis mendasari definisi populisme sayap-kanan Viktor Orbán yang menempatkan dirinya sebagai pembela "rakyat" dan pelindung "kedaulatan rakyat" dari ancaman institusi internasional seperti IMF yang dianggap sebagai representasi dari "elit-elit korup" yang gagal dalam mengelola tatanan ekonomi global. Definisi "rakyat" menurut Orbán merujuk pada etnis Hongaria, Eropa, Kristen, dan kalangan nasionalis konservatif, sedangkan "elit-elit" mengacu pada birokrat Brussel/Uni Eropa, birokrat asing, liberalis, aktivis HAM, dan afiliasi George Soros, yang mewakili kepentingan asing dan elit keuangan internasional. Kelompok "elit korup" ini diasosiasikan sebagai dalang yang membawa imigran ilegal dan "kelompok liyan" dalam arus migrasi dan pengungsi ke Hongaria lewat paket kebijakan (neo-)liberal dan migrasi. George Soros secara khusus dianggap ancaman serius bagi Hongaria di bawah Orbán karena milyarder Amerika kelahiran Hongaria ini dilihat sebagai mafia dan agen liberalisme Amerika yang mendanai aktivitas liberalisasi tatanan nasional dan jejaring CSO internasional yang membantu imigran ilegal di dalam negeri (Csehi 2019).

Sementara itu, kelompok liyan dikaitkan dengan imigran non-Eropa, Muslim, dan etnis Roma atau Gipsi yang Orbán persepsikan sebagai ancaman nyata bagi budaya Hongaria dan nilai-nilai kekristenan (Csehi 
2019). Hal ini terlihat dari sikap Orbán yang ingin membangun pagar perbatasan untuk menghentikan arus pengungsi dan menolak keras program UE tentang realokasi kuota pengungsi. Persepsi berbasis teori konspirasi atas organisasi internasional menjadi dorongan politik dalam membelah antara "rakyat" pendukung pro-pemerintah dan "musuh rakyat" pengkritik rezim Fidesz dan entitas asing dengan membakar sentimen nativisme, antiimigran dan euro-skepticism (Norris dan Inglehart 2019). Polarisasi sosial ini dibangun oleh Orbán berkaitan dengan taktik populis-nativis untuk melegitimasi upaya perubahan konstitusi dan sistem elektoral Hongaria dan tentunya menggalang dukungan mayoritas lebih besar terhadap kebijakan nasionalis konservatifnya.

Kondisi sosial Turki yang telah terbelah antara kalangan elit perkotaan dan kaum konservatif kelas menengah ke bawah membuat citra anti-kemapanan Erdoğan semakin kuat dalam mengklaim sebagai "rakyat biasa" melawan "elit-elit jahat". Arti "rakyat biasa" Turki merujuk kepada etnis Turki, kaum Muslim Sunni, Islamis konservatif, dan nasionalis relijius atau kelompok mayoritas yang identitas religio-kulturalnya terpinggirkan oleh rezim otoriter Kemalis. Sedangkan, "elit-elit jahat" diasosiasikan kepada kelompok Kemalis, sekuler, dan liberal pro-Barat dan dianggap "musuh rakyat" karena diyakini berperan sebagai proksi kepentingan militer atau asing "non-Islam" yang dahulu telah mengopresi rakyat dan lebih mengistimewakan elit-elit berkuasa daripada suara mayoritas konstituen. Dalam populisme Erdoğan, "kelompok liyan” lebih dikaitkan dengan peran politik daripada identitas religio-kultural di mana kelompok splinter yang bersebrangan dengan pemerintah dianggap mengancam stabilitas nasional seperti pemberontak Kurdi, Gulenis, Alawi/Alevi, dan komunitas politik minortias lain (Yilmaz 2021).

Berbeda dari Modi dan Orbán, dalam narasi populisnya Erdoğan cenderung mengombinasikan agama (Islamisme), nasionalisme, dan perjuangan kelas dalam mendikotomi masyarakat lewat retorika "rakyat biasa versus elit jahat". Islam merupakan elemen sentral dalam populisme Erdoğan sebagai landasan moral dalam menentukan siapa "rakyat sejati", "elit", dan "liyan". Aspek moralitas populis Islam ini bertujuan menempatkannya sebagai "pelindung" rakyat dan "penyelamat" negara dari ancaman-ancaman "musuh rakyat" yang anti-patritotis. Di samping itu, stereotip kelas sosial Turki dimanfaatkan oleh Erdoğan untuk mempertegas dikotomi ini dengan memosisikan diri sebagai bagian dari "Turki Hitam" (kelompok sosial pinggiran, kelas menengah-bawah, konservatif, mayoritas yang tertindas) yang selama delapan dekade diopresi oleh rezim yang lebih mengutamakan "Turki Putih" (kalangan elit, kelas menengah- 
atas, sekuler, memiliki privilese) dalam pemerintahan (Rogenhofer dan Panievsky 2020). Polarisasi ini turut diperkuat dengan sokongan besar dan loyalitas borjuasi konservatif daerah bagi agenda-agenda AKP yang terfokus pada perbaikan pertumbuhan, pelayanan publik, demokratisasi, dan pemberdayaan konservatisme Islam, yang sebelumnya termarjinalkan oleh elit-elit Kemalis yang terkoneksi kuat dengan borjuasi sekuler pusat (Gumuscu 2013). Dengan demikian, jangkau populisme Erdoğan pada sebagian besar irisan kelompok politik marjinal semakin melegitimasi pembelahan sosial berbasis definisi "rakyat" demi perbaikan lembaga negara dan penyingkiran elit-elit Kemalis dan simpatisannya, termasuk kelompok yang dituduh tidak patriotik, dari agenda pemerintahan AKP.

\section{Pelemahan Institusi Demokrasi lewat Diskursus Demokratis}

Kemenangan pemimpin despotik pada pemilihan umum dapat memberikannya legitimasi lebih kuat untuk menentukan pendekatan, arah, dan aturan main dalam institusi demokrasi. Namun, di tangan pemimpin otoriter baru, legitimasi cenderung disalahgunakan untuk melemahkan pelaksanaan institusi demokrasi yang akuntabel dan berpegang teguh pada supremasi hukum (the rule of law). Retorika demokratis dan konstitusional dimanfaatkan sebagai dalih untuk melegitimasi tindakan otoriter dan iliberal eksekutif atas nama "kepentingan rakyat (mayoritas)". Implikasinya, pelaksanaan amanat konstitusi diinterpretasikan atau diubah secara partisan dan bias politik dan institusi demokrasi diinstrumentalisasikan untuk mengooptasi independensi lembaga hukum dan kenegaraaan, yang seharusnya menjadi hambatan bagi otoritas absolut eksekutif (Levitsky dan Ziblatt 2018).

Secara umum, institusi demokrasi India masih dinilai stabil dan proses elektoral masih dianggap bebas dan adil seperti tergambarkan pada Gambar 2. Namun, gelagat otoritarianisme di bawah pemerintahan partai BJP pimpinan Modi terjadi dalam beberapa kasus terkait persoalan konstitusionalisme dan supremasi hukum. Pada 2018, manuver politik BJP ini terjadi dalam penunjukkan Dipak Misra, hakim junior, oleh PM Modi sebagai ketua Mahkamah Agung (MA) India. Bagi empat hakim senior, ketua MA India yang baru ini memiliki rekor buruk dalam menangani kasus kematian hakim BH Loya, hakim yang mengawasi perkara pembunuhan yang melibatkan Presiden BJP Amit Shah. Penunjukkan ini dinilai membahayakan integritas Mahkamah Agung dan demokrasi India karena pemilihan ketua ini didasari atas preferensi rezim Modi tanpa dasar rasional yang jelas (Safi 2018). Di tahun 2020, penunjukkan hakim agung 
Rajan Gogoi sebagai anggota the Upper House "Rajya Sabha", Dewan Perwakilan Negara Bagian India, oleh pemerintah sesaat sebelum masa pensiunnya dianggap sangat politis dan bentuk politik akomodasi simpatisan partai pemerintah dalam lembaga independen negara, yang dilihat sebagai ancaman serius bagi pemisahan kekuasaan yang konstitusional (Bhushan 2020).

Rangkaian tindakan pelemahan independensi peradilan ini merupakan kelanjutan upaya Modi untuk mereformasi sistem penunjukan hakim tinggi lewat rancangan undang-undang yang disahkan parlemen, tetapi ditolak MA dengan alasan sistem yang baru akan melemahkan independensi peradilan dan pemisahan kekuasaan (Jaffrelot 2016). Penolakan MA terhadap proposal Modi tersebut disebut oleh salah satu menteri Modi, Menteri Keuangan Arun Jaitley, sebagai bentuk "the tyranny of the unelected" terhadap pemerintah hasil pemilihan umum merupakan ancaman bagi demokrasi (The Indian Express 2015). Lebih lanjut, pelemahan demokrasi India juga jelas terlihat dari sentralisasi pembuatan kebijakan melalui dekrit, di mana Modi memutuskan untuk mengumumkan semua keputusan melalui siaran public address dan menolak untuk pelibatan voting parlemen dan debat formal (Chacko 2018; Rogenhofer dan Panievsky 2020)2018; Rogenhofer \& Panievsky, 2020. Upaya pelemahan lembaga independen negara ini bertujuan untuk melindungi berbagai tindakan represif dan brutal terhadap "musuh" pemerintah dari berbagai tekanan dan perlawanan oposisi dan pengkritik.

Namun, upaya pelemahan demokrasi Hongaria di bawah kekuasaan Viktor Orbán lebih efektif dan sistematis dibandingkan Modi di India. Sukses mentransformasi Hongaria sebagai rezim otokrasi elektoral pertama di UE, pemerintahan partai Fidesz menunjukkan efektivitas strategi populis otoriter Orbán dalam menjamin stabilitas kekuasaan eksekutif yang hampir absolut. Dengan dua pertiga atau 68 persen kursi super-mayoritas di parlemen, konstitusionalisme Hongaria menjadi target utama dalam upaya awal meruntuhkan fondasi demokrasi rezim di periode 2010-2014. Fidesz memanfaatkan situasi ini dengan merubah aturan dasar, mengamandemen syarat penulisan konstitusi baru, membatasi wewenang Mahkamah Konstitusi dan sistem pemilihan hakim, mengisi mayoritas jabatan komisioner di Komisi Pemilihan Umum, merestrukturisasi Otoritas Media untuk mengontrol pers sesuai preferensi partai, dan melantik loyalis sebagai presiden Hongaria (veto player). Manuver ini dilakukan untuk menyingkirkan hambatan oposisi dan CSO terhadap konstitusi baru versi Fidesz yang disahkan pada 1 Januari 2012 (Bánkuti dkk. 2012). 
Kesuksesan Fidesz dalam mengganti konstitusi baru Hongaria berdampak pada lumpuhnya sistem checks and balances dalam sistem parlemen unikameral di mana Mahkamah Konstitusi dan lembaga pengadilan dalam konstitusi lama merupakan veto players bagi pemerintah mayoritas. Namun, konstitusi baru memungkinkan Fidesz untuk mengintervensi MK dengan pembentukan Dewan Peradilan Nasional (NJO), yang bertugas untuk mengangkat hakim dan menunjuk Tünde Handó, istri petinggi Fidesz, sebagai Presiden NJO periode 20122020. Konstitusi baru juga mereformasi sistem elektoral campuran yang menguntungkan partai penguasa di masa depan. Adapun perubahan terkait prosedur pemilihan umum parlemen termasuk perubahan pemilihan umum dua putaran menjadi satu, pengurangan jumlah kursi parlemen dari 386 menjadi 199 (106 untuk distrik dan 93 untuk daftar partai), penangguhan syarat partisipasi pemilih, perubahan batas geografis antar konstituen, dan pemberian hak suara pada etnis Hongaria non-residen di luar negeri. Namun, para ahli melihat perubahan prosedur ini tidak lain hanya bentuk "persekongkolan partisan yang mengerikan" untuk memelihara status quo partai penguasa dalam pemilihan umum, tanpa harus melakukan kecurangan, dan melemahkan peluang partai-partai oposisi. Hal ini terbukti dari hasil pemilihan umum 2014 di mana Fidesz berhasil mengamankan dua pertiga suara di parlemen dengan 44 persen suara mayoritas (Levitsky dan Way 2020).

Turki di bawah Recep Tayyip Erdoğan menunjukkan sebuah ironi demokratisasi karena awal kebangkitan AKP memberikan harapan ketika berhasil melucuti kekuasaan militer lewat referendum konstitusi, hasil kudeta 1982, di 2010. Serangkaian reformasi politik dan hukum ditegakkan AKP pimpinan Erdoğan dalam dua periode awal 2002-2011 tersebut memperkuat otoritas sipil dan pejabat-pejabat terpilih dan menyingkirkan seluruh elemen dan warisan militer. Dampak positif yang ditimbulkannya pada stabilitas ekonomi dan demokratisasi semakin mempertegas letigimasi kekuasaan AKP di periode pertama. Ironisnya, reformasi ini tidak menghantarkan Turki pada konsolidasi demokrasi, tetapi pada rezim otokrasi elektoral atau "otoritarianisme kompetitif" yang terpusat kuasa personal Erdoğan (Esen dan Gumuscu 2016). Tendensi otoriter Erdoğan yang berambisi untuk melemahkan checks and balances terlihat jelas setelah pecahnya protes Gezi Park pada Juni 2013 dan skandal korupsi yang melibatkan menteri-menteri kabinet dan kerabatnya pada Desember 2013, di mana rezim AKP mengabaikan putusan peradilan dan berambisi membajak lembaga independen negara. Pada kasus Gezi Park, aparat keamanan secara brutal merepresi massa aksi dan memakan enam nyawa 
dan ratusan luka-luka. Pada kasus korupsi, AKP mengadopsi peraturan yang merestrukturisasi Dewan Tinggi Hakim dan Jaksa (HSYK) pada Pebruari 2014 dan mengatur kedudukan dan keanggotaan HSYK di bawah wewenang Menteri Kehakiman, termasuk semua penyelidikan pengadilan harus mendapatkan persetujuan pemerintah eksekutif. Hasilnya, seluruh hakim dan jaksa terlibat dalam investigasi skandal korupsi dimutasi dan digantikan dengan loyalis pro-pemerintah (Müftüler-Baç 2016).

Pelemahan otonomi lembaga peradilan ini merupakan sikap populis otoriter Erdoğan terhadap institusi demokrasi yang dianggap sebagai proksi elit atau "musuh rakyat" dalam menghalangi perwujudan "keinginan rakyat" (Dinçşahin 2012). Sejak 2014, tendensi otoriter ini mulai memperkuat pengaruh AKP di semua lini institusi negara mulai dari mengubah prosedur pemilihan yang menguntungkan petahana, membajak media-media nasional, memobilisasi sumber daya negara untuk kepentingan elektoral AKP, mengabaikan hambatan formal dan informal yang merugikan partai oposisi. Keadaan yang menguntungkan AKP ini menciptakan kondisi tak seimbang bagi kompetisi elektoral (Esen dan Gumuscu 2016). Lebih lanjut, kegagalan kudeta di 2016 menjadi babak baru bagi resilisensi rezim otokrasi Erdoğan di mana AKP menggunakan peristiwa tersebut sebagai dalih untuk melegitimasi pergantian dari sistem parlementer ke presidensialisme pada April 2017. Pergantian menuju presidensialisme pada April 2017 itu dilegitimasi oleh gagalnya upaya kudeta di 2016 yang menjadi dalih eksekutif ini untuk melakukan autogolpe atau swa-kudeta demi transformasi konstitusional yang menguntungkan kelanggengan kekuasaan petahana. Akibatnya, pemusatan kekuasaan Erdogan ini menjadi puncak dari tendensi populis otoriter sejak kemerosotan demokrasi Turki dimulai di periode kedua pemerintahan AKP (Lührmann dkk.1 ea 2017).

\section{Kontrol Sumber Alternatif Informasi}

Kontrol media dan sumber alternatif informasi menjadi taktik tak terelakkan untuk membendung resistensi demokrasi terhadap legitimasi kekuasaan populis otoriter. Hal ini dikarenakan peranan penting pers dan media sebagai pilar keempat demokrasi dalam mendorong mekanisme akuntabilitas dan partisipasi sipil terhadap penyalahgunaan wewenang. Jurnalisme independen, ekspresi budaya, dan kebebasan akademik merupakan beberapa prasyarat penting untuk menjamin tersedianya sumber alternatif informasi bagi warganegara (Dahl 1971), tetapi hal ini menjadi momok bagi ambisi hegemoni kebenaran populis anti-demokrasi. Akibatnya, penguasaan media-media arus utama dan institusi pendidikan 
oleh populis otoriter bertujuan untuk memastikan loyalitas stakeholders industri penyiaran, jurnalis, dan tokoh populer pada kepentingan rezim menjadi pra-kondisi menentukan dalam opini publik (Applebaum 2020). Implikasinya, distorsi informasi dan represi akademik melalui disinformasi dan informasi bias merupakan praktik otoriter dari pengontrolan informasi yang menjadi ancaman serius bagi kebebasan berekspresi.

Penyensoran media dan kontrol informasi alternatif di India dinilai berada di tingkat yang mengkhawatirkan bagi institusi formal dan informal dalam melindungi norma-norma demokrasi dan kebebasan informasi dibanding dengan rezim-rezim sebelumnya. Narendra Modi juga kerap menyerang media independen, terutama berbahasa Inggris, sebagai agen konspirasi media dan elit korup, terutama mereka yang kritis terhadap agenda Hindutva. Pemerintahan Modi pernah menginstruksikan Kementerian Informasi dan Penyiaran untuk memblok akses listrik NDTV, kanal berita yang kerap mengkritik rezim, selama 24 jam atas liputan investigasi tentang operasi anti-terorisme yang sensitif bagi rezim (Livemint 2016). Atas hal tersebut, pemerintah mengeluarkan aturan yang membatas peliputan media dalam isu-isu tertentu, termasuk tentang penanganan Covid-19 di India. Selain itu juga, pemerintahan BJP juga membatasi ruang gerak jurnalisme dengan memperketat perizinan media, memfitnah dan memenjarakan wartawan dalam melaksanakan fungsi kontrol demokratisnya (Rogenhofer dan Panievsky 2020).

Dampak lain dari restriksi media kritis ini juga membuat banyak media independen yang awalnya kritis tidak lagi memprotes dan mulai mendukung berbagai tindakan negara, termasuk melakukan tindakan self censorship terhadap informasi anti-BJP (Sharma 2018). Agenda nasionalisme Hindu yang dipromosikan oleh BJP banyak diperkuat oleh bantuan dari firma data solution, konsultan teknologi informasi dalam memetakan narasi dan kelompok yang pro- dan anti-BJP. Hal ini juga diperkuat dengan dukungan pasukan troll atau influencers kelas-atas di media sosial dan media berbahasa Hindi dalam mengobarkan sentimen etno-relijius para pendukung Hindutva, lewat strategi komersil untuk meningkat trafik online (Curato dan Fossati 2020). Pembatasan media dan pemanfaatan inovasi untuk agenda iliberal dan otoriter ini merupakan upaya sabotase akuntabilitas publik terhadap kinerja pemerintah dan kebebasan informasi yang, yang berdampak pada penurunan kebebasan pers India ke peringkat 140 dari 180 negara (Rogenhofer dan Panievsky 2020).

Berbeda dengan Modi, Viktor Orbán cenderung membajak media publik dan swasta dalam membatasi arus informasi alternatif yang dirasa mengancam kredibilitas rezim. Berbekal konstitusi baru yang 
menekankan kewajiban negara dalam "budaya Kristen", pemerintahan Orbán menggunakan narasi ini menjadi dalih untuk melegitimasi berbagai aktivitas yang bertentangan dengan agenda pemerintah (Bánkuti dkk. 2012). Sejak 2015, koalisi dan aliansi pemerintahan Orbán telah mengambil alih kepemilikan media-media kritis seperti Hir TV, Origo.hu, dan Indamedia Group melalui para pebisnis pro-Fidesz untuk mendominasi lanskap media nasional. Sementara itu, media oposisi Népszabadság dan Magyar Nemzet terpaksa tutup karena bangkrut dan kesulitan untuk mengakses sumber pendanaan lewat sponsor, iklan, dan insentif publik yang dipersulit otoritas berwenang. Pemerintah hanya memberikan akses sumber pendapatan pada jaringan media pro-rezim sebagai timbal balik atas dukungannya(EFJ 2018). Upaya "pembelian" media ini diperkuat oleh Otoritas Media (NMHH) lewat undang-undang media massa tahun 2010 sesuai kepentingan Fidesz sebagai partai mayoritas, di mana salah satu media oposisi dibredel karena berusaha mengungkapkan keterlibatan Orbán dalam skandal korupsi (RSF 2018). Dewan Media yang seharusnya mengontrol kerja NMHH justru ditempati oleh orang-orang pilihan Fidesz dan PM Orbán (Bogaards 2018). Rangkaian pengontrolan media ini merupakan implementasi dari upaya sistematis Fidesz dalam mengintervensi jurnalisme independen. Penguasaan media ini merupakan propaganda populis Orbán berbasis teori konspirasi dan disinformasi terhadap "musuh rakyat", yakni para pengkritik, oposisi politik, CSO, pembela HAM, media profesional, kelompok minoritas, dan imigran (Council of Europe 2021).

Selanjutnya, Fidesz berusaha menekan kebebasan akademik Hongaria dengan sejumlah kebijakan yang mengancam otonomi institusi keilmuan dengan sejumlah larangan aktivitas dan lembaga pendidikan. Pada periode pertama berkuasa, Orbán mereformasi sistem pendidikan tinggi dengan menempatkan jabatan baru, kanselor, di semua perguruan tinggi atas penunjukkan PM untuk mengelola keuangan dan melaksanakan kebijakan pemerintah lainnya di lembaga tersebut (Kocsis 2021). Pada tahun 2017, Orbán dan Fidesz berhasil merevisi undang-undang pendidikan tinggi nasional tahun 2011, yang dikenal dengan "Lex CEU", untuk mengatur tentang pengoperasian universitas asing yang pada intinya hanya menjadi basis legal untuk menyingkirkan Central European University, universitas terkemuka milik Soros, dari Hongaria karena dianggap menyebarkan paham liberalisme, pro-imigrasi, dan masyarakat terbuka ala Amerika (Bárd 2020). Ancaman kebebasan akademik ini diperparah dengan disahkannya undang-undang tentang penelitian, pengembangan, dan inovasi ilmiah pada 1 Agustus 2019 yang mengamanatkan pemisahan banyak lembaga penelitian penting dari Academy of Sciences Hongaria ke lembaga baru, 
Eötvös Loránd Research Network (ELKH), yang dipimpin para loyalis Fidesz dengan wewenang menentukan pendanaan proyek ilmiah sesuai kebutuhan pemerintah (Gall 2019). Represi akademik juga terlihat dari pelarangan program studi gender di universitas publik karena dianggap terlalu liberal dan tidak sesuai ideologi pemerintah. Rentetan manuver politik Fidesz ini merupakan upaya strategis untuk membungkam suara kritis dan pikiran independen (Gall 2019).

Dalam mengontrol sumber informasi alternatif, Erdoğan menggabungkan kedua tindakan otoriter Modi dan Orbán baik itu membajak media arus-utama melalui konglomerasi lingkaran pro-pemerintah dan mendiskreditkan media-media kritis. Lanskap media Turki sebelum era AKP didominasi oleh empat korporasi besar (Doğan, Merkez, Çukurova, Star Groups) dengan oritentasi politik beragam, tetapi berangsur-angsur diambil alih oleh kelompok bisnis pro-AKP sejak medio-2007, baik melalui akuisisi atau penyitaan negara. Kerentanan korporasi media arus-utama dari pembajakan dan tekanan rezim AKP berkaitan erat dengan ketergantungan pemilik media dengan kontrak kerja dengan pemerintah di banyak sektor publik (Yılmaz 2016). Dominasi media-media milik negara dan pro-rezim yang diperkuat dengan Dewan Tinggi Radio dan Televisi (RTÜK) yang bertugas mengontrol pemberitaan dan membatasi akses oposisi pada kanal publik maupun swasta agar selaras dengan kepentingan pemerintah. RTÜK ini berperan besar dalam menekan dan mendiskreditkan media-media yang bertentangan dengan rezim melalui denda, penangguhan program ataupun pembatalan izin. Menurut survei yang melibatkan petinggi dan awak media, 96 persen responden berpendapat bahwa pemerintahan AKP merupakan penentu konten berita, dan 91 persen setuju bahwa media tidak meliput berita penting karena tekanan pemerintah (Esen dan Gumuscu 2016).

Rezim Erdoğan mengeksploitasi tekanan hukum untuk merestriksi akses informasi dan merepresi pers independen dalam mengontrol sumber informasi alternatif. Pemerintah mengeluarkan undang-undang internet tahun 2007 dan 2014 dengan memblokir website dan sosial media karena terlalu bebas menyoroti tindakan kekerasan negara terhadap sipil, khususnya pasca aksi protes Gezi Park. Aparatur pemerintah juga memanfaatkan Undang-Undang Penyensoran dan Defamasi untuk mengkriminalisasi pekerja media yang dituduh menghina keturkian dan lembaga negara (Y1lmaz 2016)transformation towards a more European model of governance through Europeanisation is not a linear process, but a differentiated one. Adverse consequences for Europeanisation (i.e. deEuropeanisation. Sejak 2012, kasus-kasus yang berusaha membungkam 
pers independen sering ditemukan dan berujung dengan pemecatan, penahanan, atau pemenjaraan. Periode 2013-2014, tercatat lebih dari 482 jurnalis kehilangan pekerjaan akibat UU penyensoran dan lebih dari 796 warga ditindak atas pencemaran nama baik PM Erdoğan termasuk jurnalis (50 kasus) dan tokoh oposisi (281 kasus). Namun, sebagian besar dari kasus pembungkaman pers ini disebabkan oleh tuntutan pemerintah yang menginstrumentalisasi Undang-Undang Anti-Teror 2006 dengan menarget jurnalis-jurnalis kritis yang dituduh menyebarkan propaganda "organisasi teroris" seperti jurnalis pro-Kurdi atau terafiliasi Gerakan Gülen. Pada 2010, tercatat sekitar 150 jurnalis ditahan di mana 33 orang di antaranya dihukum 365 tahun penjara. Pada 2012, lebih dari 100 jurnalis ditahan atas tuduhan pelanggaran UU Anti-Teror. Periode ketiga Erdoğan menjadikan Turki negara pemenjara jurnalis tertinggi di dunia (Castaldo 2018; Esen dan Gumuscu 2016).

\section{Represi Oposisi dan Pengkritik}

Sejak berkuasa di 2014, pemerintahan BJP terus merepresi dan mengontrol secara organisasi masyarakat sipil (civil society organisations[CSO]). Hal ini terlihat dari kebijakan pemerintah yang memperketat regulasi Foreign Contributions Regulation Act (FCRA) untuk membatasi keluar-masuk dan fungsi CSO, khususnya hambatan penggunaan kontribusi asing dalam wilayah India. Greenpeace merupakan salah satu organisasi yang rekening banknya dibekukan pemerintah BJP karena dituduh sebagai organisasi yang dibiayai asing untuk kegiatan "anti-nasional." Tindakan represif ini dilakukan setelah pemerintah mendapat laporan dari Badan Intelijen bahwa organisasi asing diklaim melakukan hasutan dan propaganda penolakan terhadap berbagai proyek infrastruktur industri ekstaktif yang dianggap berdampak negatif pada pertumbuhan ekonomi India (Chacko 2018)2018. Begitupula beberapa organisasi kritis lain yang dilarang mendapatkan bantuan pendanaan Asing setelah mengkritik sikap dan kebijakan pemerintahan Modi yang dianggap problematik seperti pada Kerusuhan Gujarat 2002. Secara umum, jumlah organisasi non-pemerintah yang resmi mendapatkan pendanaan asing turun drastis dari 40.000 ke 16.000 sejak BJP menang pemilu 2014 (McDonnell dan Cabrera 2019).

Selain mengontrol organisasi sipil, rezim BJP pimpinan Modi sering memanfaatkan undang-undang tentang hasutan, defamasi, dan kontraterorisme untuk membungkam para oposisi, pengkritik, dan bahkan merepresi masyarakat sipil. Bagian khusus dari undang-undang defamasi menyatakan bahwa siapa saja yang "dapat menyebabkan kebencian 
atau menghina, atau mencoba menimbulkan ketidakpuasan terhadap pemerintah" baik berupa "kata-kata, lisan atau tertulis, atau tanda atau representasi visual", dapat ditahan dari dua tahun sampai seumur hidup. Sejak berlaku pada Mei 2016, undang-undang ini sering digunakan untuk mengkriminalisasi jurnalis dan media kritis terhadap kebijakan pemerintahan. Sejak Modi berkuasa, setidaknya 7000 orang didakwa melakukan penghasutan karena mengkritik partai BJP, di antaranya 150 orang yang dituduh menghina Perdana Menteri Modi (Halarnkar 2021; Hellmeier dkk. 2021)untuk mengintimidasi dan menahan oposisi politik, aktivis mahasiswa, pembela HAM, akademisi, dan pegiat CSO lain yang terlibat protes damai terhadap kebijakan The Citizenship Amandment Act (CAA) yang dianggap melegitimasi deskriminasi berbasis agama karena hanya memberi kewarganeraan pada pendatang non-Muslim dan bertentangan dengan konstitusi sekuler India (FIDH 2020).

Lebih lanjut, tuduhan penghasutan juga menyasar aktivisme dan kebebasan akademik di perguruan tinggi yang sempat menjadi perhatian internasional. Pada Pebruari 2016, Kanhaiya Kumar, Presiden Student Union di Jawaharlal Nehru University (JNU), ditangkap dengan tuduhan "anti-India" setelah video viral dirinya saat proses menentang eksekusi mati Afzal Guru, tokoh separatis/milisi Khasmir, di 2013. Bagi partai BJP, para pemrotes tersebut sebagai "pengkhianat", aktivisme kritis dari organisasi mahasiswa tersebut juga tidak dapat ditolerir dan itu merupakan bagian dari parasit "elit liberal" dan sentimen "anti-nasional" yang antagonis terhadap warga India. Pemerintahan Modi juga menyasar mahasiswa dan aktivis di universitas yang terlibat dalam akti protes yang dianggap anti-nasional dengan kekerasan dan intimidasi aparatur keamanan dan kelompok Hindu nasionalis (Chacko 2018).

Berbeda dengan India yang menggunakan pendekatan koersif dalam membungkam oposisi sipil, kondisi kebebasan sipil di Hongaria dalam beberapa hal masih relatif damai dan stabil, mengingat kubu pro-demokrasi bisa memobilisasi perlawanan terhadap rezim populis Orbán. Namun, pemerintahan Fidesz terus merombak konstitusi dan aturan hukum dalam membatasi kubu oposisi politik dan masyarakat sipil yang kritis. Status super mayoritas Fidesz di parlemen memberikan Orbán kapasitas dominan dalam amandemen konstitusi tanpa hambatan, termasuk menyingkirkan dan memecah belah partai-partai oposisi dalam proses pemerintahan. Fidesz memanfaatkan lembaga formal untuk memobilisasi sumberdaya negara untuk kepentingan partai demi memblokade peluang partai oposisi untuk mengakses kekuasaan di pemilihan umum berikutnya (OSCE 2018) Kantor Audit Negara (Állami Számvevőszék [ASZ]) merupakan salah 
satu contoh bagaimana Fidesz memonitor aktivitas politik dan keuangan partai oposisi. Misalnya, Partai Jobbik, oposisi nasionalis sayap-kanan, sering menjadi target audit, di antaranya sanksi denda 1.2 Juta USD setelah menampilkan billboard yang dituduh berisi kampanye anti-pemerintah (Reuters 2018a) dan penangguhan pendanaan negara setelah auditor, mantan anggota parlemen Fidesz, menyatakan adanya penyimpangan dan intransparansi dalam keuangan partai oposisi ini (ABC News 2020).

Dominasi Fidesz dalam semua lini perpolitikan Hongaria dan sumber daya negara menutup banyak peluang bagi masyarakat sipil untuk berperan aktif dalam mengawasi roda kekuasaan politik penguasa. Bersamaan dengan represi media dan kebebasan akademik, CSO di Hongaria juga turut mengalami represi dan intimidasi politis secara sistematis, khususnya yang memiliki agenda kontradiktif dengan pemerintah. Pada tahun 2014, polisi melakukan penggerebekan tanpa pemberitahuan terhadap kantor dan rumah pimpinan Ökotárs and Demnet, organisai non-pemerintah (NGO) penyalur dana hibah bidang kemanusiaan Norwegia di Hongaria, yang juga masuk daftar organisasi "musuh" pemerintahan Orbán (Varga 2014) Represi terhadap NGO independen semakin dilegitimasi oleh negara dengan disahkannya paket undang-undang migrasi "Stop Soros" pada tahun 2018. Hukum ini bertujuan untuk menghentikan arus imigrasi "penduduk asing" dan memidanakan NGO dan aktivitas advokasi dan bantuan terhadap para imigran, pengungsi dan pencari suaka di Hongaria, termasuk pengenaan pajak 25 persen terhadap pendanaan asing dalam aktivitas NGO (Reuters 2018b). Legislasi ini merupakan bukti dari sikap anti-imigrasi dan janji politik Orbán untuk melarang aktivitas CSO liberal yang dituduh "agen asing" atau "agen Soros" karena mendalangi imigrasi masif dalam menghancurkan nilai-nilai peradaban Eropa (Csehi 2019). Karena itu, rangkaian undang-undang yang disahkan pemerintahan Fidesz, yang di antaranya banyak dibatalkan oleh Mahkamah Eropa karna tidak sesuai dengan nilai-nilai UE, menunjukkan intensifnya pelanggaran sistemik terhadap hak-hak politik dan kebebasan sipil yang ditenggarai oleh rezim populis Orbán.

Lebih sistematis dari Fidesz dan BJP, represi rezim AKP pimpinan Erdoğan terhadap oposisi politik dan sosial terbagi dalam dua: "pendekatan lunak" di dua periode awal (2002-2011) dan "pendekatan keras" sejak periode ketiga (2011-sekarang). Pada periode awal, Erdoğan lebih fokus pada pembentukan citra demokratis dan reformis pemerintah AKP baik di tingkat domestik maupun internasional yang bebas dari pengaruh warisan otoriter Kemalis dan militer. Erdoğan mengadopsi strategi pragmatis dalam meningkatkan pembangunan ekonomi, kompromi isu keagamaan dengan 
sekulerisme-Kemalisme, proses keanggotaan Uni Eropa, harmonisasi hukum Turki-UE, dan reformasi struktural yang menekankan supremasi sipil atas militer. Oposisi tidak direpresi secara brutal tetapi dibatasi akses material dan institusional untuk memperkuat basis elektoral dan kampanye politiknya melalui dominasi eksklusif loyalis AKP atas aparatur negara, media, dan berbagai sektor publik maupun swasta. Misalnya, pengerahan pegawai negeri untuk mendukung kampanye AKP dan menghambat upaya kampanye oposisi dengan pengapusan poster-poster, penyitaan materi kampanye yang dianggap anti-pemerintah oleh kepolisian, dan penolakan penggunaan tempat publik untuk kampaye oposisi lewat tekanan pemerintah. Selain itu, sejak terjadinya "pengadilan Ergenekon" pada tahun 2008 yang berusaha mengungkapkan persekongkolan organisasi ultranasionalis terkoneksi militer untuk menggulingkan pemerintah, AKP mulai menarget figur-figur oposisi dan menggugat aktivis, CSO, dan akademisi yang dituduh terlibat dengan aksi subversif, serta jurnalis yang dituduh melanggar prinsip kerahasiaan proses pengadilan (Castaldo 2018; Y1lmaz 2016)

Memasuki periode ketiga di 2011, Erdoğan mulai mengadopsi pendekatan keras terhadap oposisi, masyarakat sipil, dan kelompok pengkritik dengan penggunaan intimidasi, koersi, dan kekerasan. Pasca protes Gezi Park, Erdoğan mulai mempertegas dikotomi populisnya dalam melegitimasi tindakan represif negara terhadap massa aksi protes sebagai perlindungan "kepentingan rakyat", sedangkan para pemrotes, oposisi ekstra-parlementer, dan masyarakat sipil non-loyalis sebagai "kelompok jahat" dan "asing" bagi masyarakat Turki (Rogenhofer dan Panievsky 2020). Represi terhadap partai oposisi semakin kentara setelah peristiwa gagalnya kudeta pada 2016 yang memakan korban 265 nyawa dan 2000 orang lukaluka ini dipolitisasi oleh Erdoğan untuk mendeklarasikan "kedaruratan" negara. Seperti halnya di Hongaria, kedaruratan ini memberikan Erdoğan otoritas untuk menangguhkan pemberlakuan hukum "normal" dan Kovensi HAM Eropa, serta melegalkan penahanan pengkritik dan oposisi yang diindentifikasi rezim terlibat dalam kudeta. Hasilnya, pimpinan dan beberapa anggota parlemen dari oposisi CHP dan Partai Demokrasi Rakyat (HDP) ditahan dan belasan wali kota di daerah-daerah Kurdi digantikan berdasarkan penunjukan AKP, 50.546 orang dipenjara, 103.824 pegawai negeri di pecat, 166 dalam pengawasan, ratusan advokat ditahan, perusahan swasta tertuduh disita, dan 150 media, lebih dari 1000 CSO dan yayasan secara resim ditutup oleh negara lewat dekrit saja (Castaldo 2018). Puncak dari pembatasan kebebasan sipil dan institusi demokrasi berbagai hukum adalah pemerintahan AKP berhasil mengamandemen 18 pasal- 
pasal konstitusi di 2017 tentang transfer kekuasaan dari sistem parlementer ke sistem presidensil, yang artinya melegitimasi sentralisasi kekuasaan presiden Erdogan (Y1lmaz \& Turner 2019).

\section{Kesimpulan}

Artikel ini telah menunjukkan bahwa, sebagaimana dilihat dalam proses otokratisasi di India, Hongaria, dan Turki, kemunduran demokrasi ke otokrasi sangat bergantung pada keterampilan pemimpin petahana dalam mengeksploitasi retorika populis yang berhasil memikat dukungan rakyat mayoritas demi melegitimasi tindakan otoriter dan iliberal rezim penguasa. Meskipun terdapat variasi konteks politik dalam otokratisasi, ketiga populis pertahana ini sama-sama mendapatkan momentum kebangkitan dari kegagalan rezim pendahulu dalam mengatasi kekecewaan sebagian besar penduduk terhadap problem sosio-ekonomi dan kultural. Begitu pula dengan konstruksi wacana, ketiga pemimpin populis ini mengklaim diri sebagai penyelamat "rakyat" dari "elit-elit" dan "musuh rakyat" berbasis diskursus etno-religius dan etno-nasional, nasionalisme Hindu, kekristenan Eropa, dan Islamisme konservatif dalam mempolarisasi antara kelompok silent majority dan "minoritas korup/asing". Politisasi kekecewaan dan polarisasi sosial berbasis diskursus kultural adalah dua bentuk manuver populisme otoriter yang mengeksploitasi narasi kerakyatan untuk menyabotase akuntabilitas pemerintahan demokratis dan partisipasi publik. Akibatnya, efektivitas populisme dalam mengarusutamakan interpretasi demokrasi mayoritarianisme pada pelaksanaan rezim kekuasaan memberi pemimpin petahana legitimasi lebih kuat untuk mengontrol informasi alternatif dan merepresi oposisi dan pengkritik pemerintah.

Dari perbandingan mekanisme di India, Hongaria, dan Turki, kita bisa melihat bahwa proses kemunduran demokrasi sangat terkait erat dengan pergeseran perimbangan kekuataan antar koalisi-koalisi politik. Pergeseran ini tentunya lebih menguntungkan koalisi atau pihak politik petahana karena dapat memobilisasi dukungan dan sikap partisan publik dengan memanfaatkan sumberdaya negara yang harusnya bebas dari kepentingan manapun. Hubungan kekuasaan yang asimetris antara petahana dan oposisi ini merusak esensi rezim demokrasi yang kompetitif, partisipasif, akuntabel, dan penghormatan terhadap hak dan kebebasan.

Mekanisme kebangkitan pemimpin otoriter ini sangat berpotensi kuat terjadi juga di negara-negara dengan kualitas demokrasi yang semakin merosot, khususnya pada negara dengan kondisi-kondisi berikut: Pertama, institusi demokrasi yang rentan disusupi kubu politik anti-demokratis yang berasal dari internal partai politik arus-utama mengaburkan komitmen 
otoriter dan illiberalnya dalam balutan politik pencitraan, akomodasi, dan klaim 'pembaharuan"; kedua, absennya peran sentral ideologi dalam visi, diskursus, dan sikap suatu partai atau politisi yang sering kontradiktifdengan dan komitmen pro-demokrasi; ketiga, adanya keinginan publik terhadap pemimpin "reformis" yang berasal dari luar lingkaran elit-elit mapan dalam menstabilkan kondisi sosio-ekonomi dan sosi-kultural negara yang bebas dari berbagai hambatan, karena bisa jadi hambatan tersebut adalah tekanan atau mekanisme akuntabilitas demokrasi; keempat, adanya harapan publik terhadap pemimpin kuat dan tegas untuk menciptakan rezim dalam menciptakan pemerintahan yang partisipatif, inklusif, bebas korupsi, dan berpihak pada rakyat, merupakan sinyalemen kuatnya preferensi publik terhadap personalisasi kekuasaan dibandingkan kepercayaan politik yang terlembagakan secara demokratis dan sistem check and balance berfungsi optimal. Dengan demikian, empat indikator ini dapat menjadi "pengingat" bagi warga dan kelompok yang menginginkan demokrasi berfungsi baik dalam pelaksanaan pemerintahaan yang akuntabel dan menghormati kebebasan.

Kebangkitan otoritarianisme baru di tengah demokrasi menunjukkan bahwa sistem demokrasi dan konstitusi sebagai dasar tidak dapat berjalan sendiri. Keberhasilannya ditentukan oleh pemimpin politik dan juga warganegara yang berkomitmen kuat terhadap norma-norma demokrasi dan menolak bentuk apa pun dari kompromi terhadap eksistensi politik dan pemimpin otoriter. Dengan demikian, warganegara pro-demokrasi berperan sentral dalam mengawasi dan menjamin pengejawantahan amanat konstitusi dan nili-nilai filosofis dari demokrasi menjadi tindakan konkret yang bisa memperkuat rezim demokrasi dalam mewujudkan sistem yang adil, setara, dan bersih.

\section{Referensi}

ABC News. 2020. Hungary: Auditor Suspends State Funding of Opposition Party. ABC News, Mei 21. Diakses dari (https://abcnews.go.com/ Business/wireStory/hungary-auditor-suspends-state-fundingopposition-party-70812951).

Abts, Koen, dan Stefan Rummens. 2007. "Populism versus Democracy". Political Studies 55(2): 405-424. https://doi.org/10.1111/j.14679248.2007.00657.x

Applebaum, Anne. 2020. Twilight of Democracy: The Seductive Lure of the Authoritarian State. New York: Doubleday. 
Babones, Salvatore. 2018. The New Authoritarianism: Trump, Populism, and the Tyranny of Experts (1st edition). Cambridge: Polity.

Bánkuti, Miklos, Gaboi Halmai, dan Kim Lane Scheppele. 2012. "Hungary's Illiberal Turn: Disabling the Constitution". Journal of Democracy 23(3):138-146. https://doi.org/10.1353/jod.2012.0054

Bárd, Petra. 2020. "The Rule of Law and Academic Freedom or the Lack of It in Hungary". European Political Science 19(1): 87-96. https://doi.org/10.1057/s41304-018-0171-x.

Bayer, Lili. 2020. "Human Rights and Greta on Hungarian State Media Watch List". POLITICO. March 2. Diakses dari (https://www. politico.eu/article/hungarian-state-media-not-free-to-report-ongreta-thunberg-human-rights/).

Becker, Jens. 2010. "The Rise of Right-Wing Populism in Hungary". SEER: Journal for Labour and Social Affairs in Eastern Europe 13(1): 29-40.

Bermeo, Nancy. 2016. "On Democratic Backsliding". Journal of Democracy 27(1): 5-19. https://doi.org/10.1353/jod.2016.0012

Bhushan, Prashant. 2020. "In Upper House Nomination, a Fall for 'Aloofness'." The Hindu, March 19. Diakses dari (https://www. thehindu.com/opinion/lead/in-upper-house-nomination-a-fallfor-aloofness/article31101941.ece).

Boese, Vanessa A., Staffan I. Lindberg, and Anna Lührmann. 2021. "Waves of Autocratization and Democratization: A Rejoinder." Democratization 28(6): 1-9. https://doi.org/10.1080/13510347. 2021.1923006.

Bogaards, Matthijs. 2018. "De-democratization in Hungary: Diffusely Defective Democracy." Democratization 25(8): 1481-1499. https://doi.org/10.1080/13510347.2018.1485015

Canovan, Margaret.1981. Populism. New York: Harcourt Brace Javanovich.

Cassani, Andrea, dan Luca Tomini. 2019. Autocratization in Post-Cold War Political Regimes. New York: Palgrave Macmillan. https:// doi.org/10.1007/978-3-030-03125-1

Castaldo, Antonino. 2018. "Populism and Competitive Authoritarianism in Turkey". Southeast European and Black Sea Studies 18(4): 467-487. https://doi.org/10.1080/14683857.2018.1550948

Cerutti, Furio. 2017. Conceptualizing Politics: An Introduction to Political Philosophy. London: Routledge. 
Chacko, Priya. 2018. "The Right Turn in India: Authoritarianism, Populism and Neoliberalisation." Journal of Contemporary Asia 48(4): 541-565. https://doi.org/10.1080/00472336.2018.1446546

Council of Europe. 2021. It is High Time for Hungary to Restore Journalistic and Media Freedoms. Commissioner for Human Rights. Diakses dari (https://www.coe.int/en/web/commissioner/view/-/asset publisher/ugj3i6qSEkhZ/content/it-is-high-time-for-hungary-torestore-journalistic-and-media-freedoms).

Csehi, Robert. 2019. "Neither Episodic, Nor Destined to Failure? The Endurance of Hungarian Populism after 2010." Democratization 26(6):1011-1027. https://doi.org/10.1080/13510347.2019.1590 814

Curato, Nicole, and Diego Fossati. 2020. "Authoritarian Innovations: Crafting Ssupport for a Less Democratic Southeast Asia." Democratization 27(6): 1006-1020. https://doi.org/10.1080/135 10347.2020.1777985

Dahl, Robert A. 1971. Polyarchy: Participation and Opposition. New Haven: Yale University Press.

Diamond, Larry. 2015. "Facing Up to the Democratic Recession." Journal of Democracy 26(1): 141-155. https://doi.org/10.1353/ jod.2015.0009

Dinçşahin, Şakir. 2012. "A Symptomatic Analysis of the Justice and Development Party's Populism in Turkey, 2007-2010." Government and Opposition 47(4):618-640. https://doi. org/10.1111/j.1477-7053.2012.01377.x

European Federation of Journalist. 2018. "Hungary: Hir TV News Channel Taken Over by the Government." Europeanjournalists. org, August 7. Diakses dari (https://europeanjournalists.org/ blog/2018/08/07/hungary-hir-tv-news-channel-taken-over-bythe-government $/ 0$.

Esen, Berk, dan Sebnem Gumuscu. 2016. "Rising Competitive Authoritarianism in Turkey." Third World Quarterly 37(9):15811606. https://doi.org/10.1080/01436597.2015.1135732

Ezrow, Natahsa M., dan Erica Frantz. 2011. Dictators and Dictatorships: Understanding Authoritarian Regimes and Their Leaders. New York: Bloomsbury Publishing. 
FIDH. 2020. "India: Release Human Rights Defenders at Risk in the Context of COVID-19.", FIDH.org, May 26. Diakses dari (https://www. fidh.org/en/issues/human-rights-defenders/india-release-humanrights-defenders-at-risk-in-the-context-of-covid).

Foa, Roberto S., dan Yascha Mounk. 2017. "The Signs of Deconsolidation." Journal of Democracy 28(1): 5-15. https://doi.org/10.1353/ jod.2017.0000

Frantz, Erica. 2018. Authoritarianism: What Everyone Needs to Know. Oxford: Oxford University Press.

Gall, Lidya. 2019. "Hungary Renews its War on Academic Freedom." Human Rights Watch, July 2. Diakses dari (https://www.hrw.org/ news/2019/07/02/hungary-renews-its-war-academic-freedom).

Geddes, Barbara. 1999. "What Do We Know About Democratization After Twenty Years?" Annual Review of Political Science 2(1):115144. https://doi.org/10.1146/annurev.polisci.2.1.115

Gidron, Noam, and Bart Bonikowski. 2013. "Varieties of Populism: Literature Review and Research Agenda". Social Science Research Network. Diaksed dari (https://papers.ssrn.com/ abstract $=2459387$ ).

Glasius, Marlies. 2018. "What Authoritarianism is ... and is Not: A Practice Perspective." International Affairs 94(3): 515-533. https://doi. org/10.1093/ia/iiy060

Gleditsch, Kristian S., dan Michael D. Ward. 2006. "Diffusion and the International Context of Democratization." International Organization 60(4):911-933. https://doi.org/10.1017/ S0020818306060309

Gumuscu, Sebnem. 2013. "The Emerging Predominant Party System in Turkey." Government and Opposition 48(2): 223-244. https:// doi.org/10.1017/gov.2012.13

Haggard, Stephan, and Robert Kaufman. 2021. Backsliding: Democratic Regress in the Contemporary World. Cambridge: Cambridge University Press.

Halarnkar, Samar. 2021. "India is Turning to Colonial-Era Laws to Silence Journalists." Open Democracy, February 3. Diakses dari (https:// www.opendemocracy.net/en/openindia/india-turning-colonialera-laws-silence-journalists/). 
Hellmeier, Sebastian et al. 2021. "State of the World 2020: Autocratization Turns Viral." Democratization 28(6): 1053-1074. https://doi.org $/ 10.1080 / 13510347.2021 .1922390$

Huntington, Samuel P. 1991. The Third Wave: Democratization in the Late Twentieth Century. Oklahoma: University of Oklahoma Press.

Inglehart, Ronald F., and Pipa Norris. 2016. "Trump, Brexit, and the Rise of Populism: Economic Have-Nots and Cultural Backlash." HKS Working Paper No. RWP16-026 Diakses dari (https://papers. ssrn.com/abstract $=2818659$ ).

Jaffrelot, Christophe. 2016. "An Ill-judged Conflict." The Indian Express, November 23. Diakses dari (https://indianexpress.com/article/ opinion/columns/supreme-court-pending-cases-judiciaryappointment-vacancies-4390364/).

Kocsis, Árpad. 2021. "The Shift in Governance Models for Hungarian Universities." Heinrich-Böll-Stiftung, June 14. Diakses dari (https://cz.boell.org/en/2021/06/14/shift-governance-modelshungarian-universities).

Levitsky, Steven, dan Lucan Way. 2015. "The Myth of Democratic Recession.” Journal of Democracy 26(1): 45-58. https://doi. org/10.1353/jod.2015.0007

Levitsky, Steven, dan Lucan Way. 2020. "The New Competitive Authoritarianism." Journal of Democracy 31(1): 51-65. https:// doi.org/10.1353/jod.2020.0004

Levitsky, Steven, dan Daniel Ziblatt. 2018. How Democracies Die. New York: Crown.

Linz, Juan J. 1964. "An Authoritarian Regime: The Case of Spain.” Pp. 291-314 dalam Cleavages, Ideologies and Party Systems: Contributions to Comparative Political Sociology, edited by Erik Allard dan Yrjo Littunen. Helsinki: Transactions of the Westermarck Society.

Livemint.com. 2016. "NDTV India Blackout: A Case of Government Overreach." Livemint.com, November 6. Diakses dari (https:// www.livemint.com/Opinion/0ldRPSAEiPQGINOCKXWrTI/ NDTV-India-blackout-A-case-of-govt-overreach.html).

Lührmann, Anna. 2021. "Disrupting the Autocratization Sequence: Towards Democratic Resilience." Democratization 28(5): 10171039. https://doi.org/10.1080/13510347.2021.1928080 
Lührmann, Anna, dan Staffan I. Lindberg. 2019. "A Third Wave of Autocratization Is Here: What Is New About It?" Democratization 26(7):1095-1113. https://doi.org/10.1080/13510347.2019.15820 29

Maerz, Sheraphine F. et al. 2020. "State of the World 2019: Autocratization Surges - Resistance Grows.” Democratization 27(6): 909-927. https://doi.org/10.1080/13510347.2020.1758670

Margiansyah, Defbry. 2019. "Populisme di Indonesia Kontemporer: Transformasi Persaingan Populisme dan Konsekuensinya dalam Dinamika Kontestasi Politik Menjelang Pemilu 2019.” Jurnal Penelitian Politik 16(1): 47-68. https://doi.org/10.14203/jpp. v16i1.783

Margiansyah, Defbry. 2020. "Inovasi dan Ketidakpastian: Menuju Perspektif Baru Kekuasaan dalam Politik Global." Jurnal Penelitian Politik 17(1):141-156. https://doi.org/10.14203/jpp. v17i1.863

McDonnell, Duncan, dan Luis Cabrera. 2019. The Right-Wing Populism of India's Bharatiya Janata Party (And Why Comparativists Should Care)." Democratization 26(3):484-501. https://doi.org /10.1080/13510347.2018.1551885

Mickey, Robert, et al. 2017. "Is America Still Safe for Democracy? Why The United States is in Danger of Backsliding." Foreign Affairs 96(May/June): 20-29.

Miklós, Sebok, dan Jasper Simons. 2021. How Orbán Won? Neoliberal Disenchantment and the Grand Strategy of Financial Nationalism to Reconstruct Capitalism and Regain Autonomy." Socio-Economic Review mwab052. https://doi.org/10.1093/ser/ mwab052

Moffitt, Benjamin. 2016. The Global Rise of Populism. Stanford: Stanford University Press.

Morgenbesser, Lee. 2020. "The Menu of Autocratic Innovation." Democratization 27(6): 1053-1072. https://doi.org/10.1080/135 10347.2020.1746275

Mudde, Cas. 2004. "The Populist Zeitgeist." Government and Opposition 39(4):542-563. https://doi.org/10.1111/j.14777053.2004.00135.x 
Mudde, Cas, dan Cristóbal Rovira Kaltwasser. 2017. Populism: A Very Short Introduction (2nd edition). Oxford: Oxford University Press.

Müftüler-Baç, Meltem. 2016. "The Pandora's Box: Democratization and Rule of Law in Turkey." Asia Europe Journal 14(1):61-77. https://doi.org/10.1007/s10308-015-0435-9

Müller, Jan-Werner. 2016. What Is Populism? Philadelphia: University of Pennsylvania Press.

Norris, Pippa, dan Robert Inglehart. 2019. Cultural Backlash: Trump, Brexit, and Authoritarian Populism. Cambridge: Cambridge University Press.

OSCE. 2018. Overlap of State and Ruling Party Resources Undermines Contestants' Ability to Compete on Equal Basis in Hungary Elections, OSCE/ODIHR Observers Say. OSCE: Organization for Security and Co-Operation in Europe. https://www.osce.org/ odihr/elections/hungary/377404

Pappas, Takis S. 2014. "Populist Democracies: Post-Authoritarian Greece and Post-Communist Hungary." Government and Opposition 49(1): 1-23. https://doi.org/10.1017/gov.2013.21

Plattner, Marc F. 2019. "Illiberal Democracy and the Struggle on the Right." Journal of Democracy 30(1): 5-19. https://doi.org/10.1353/ jod.2019.0000

Reuters. 2018. "Hungary Fines Main Opposition Party over Billboards Funded by Orban Foe." Reuters, January 8. Diakses dari (https://www.reuters.com/article/us-hungary-jobbik-fineidUSKBN1EX1JI).

The Guardian. 2018. "Hungary Steps Up Anti-Immigration Stance with Plans for NGO Tax." The Guardian, June 19. Diakses dari (https://www.theguardian.com/world/2018/jun/19/hungary-antiimmigration-plans-ngo-tax-orban-bill-criminalise-aid).

Rogenhofer, Julis M., dan Ayala Panievsky. 2020. "Antidemocratic Populism in Power: Comparing Erdoğan's Turkey with Modi's India and Netanyahu's Israel." Democratization 27(8): 13941412. https://doi.org/10.1080/13510347.2020.1795135

RSF. 2018. "One of Hungary's Last Critical Media Outlets Taken Over by Orbán Allies." Reporters Without Borders, August 3. Diakses dari (https://rsf.org/en/news/one-hungarys-last-critical-mediaoutlets-taken-over-orban-allies). 
Safi, Michael. 2018. "India's Top Judges Issue Unprecedented Warning Over Integrity of Supreme Court." The Guardian, January 12. Diakses dari (https://www.theguardian.com/world/2018/jan/12/ india-supreme-court-judges-integrity-dipak-misra).

Sharma, Anuradha. 2018. "Modi's Strange Relationship with the Truth: The Indian Prime Minister Only Likes News that Flatters Him. Plus John Lloyd on Why We Should be More Concerned about Threats to Indian Media than US Media." Index on Censorship 47(3): 74-77. https://doi.org/10.1177/0306422018800406

Snyder, Timothy. 2017. On Tyranny: Twenty Lessons from the Twentieth Century. New York: Crown.

Svolik, Milan W. 2020. "When Polarization Trumps Civic Virtue: Partisan Conflict and the Subversion of Democracy by Incumbents." Quarterly Journal of Political Science 15(1): 3-31. https://doi. org/10.1561/100.00018132

The Indian Express. 2015. "Arun Jaitley on NJAC Verdict: Democracy Cannot be "Tyranny of the Unelected"." The Indian Express, October 19. Diakses dari (https://indianexpress.com/article/ india/india-news-india/njac-sc-verdict-democracy-cannot-betyranny-of-the-unelected-says-arun-jaitley/).

Varga, Áron. 2014. "Police Raids against Hungarian NGOs". Heinrich Böll Stiftung, September 30. Diakses dari (https://eu.boell.org/ en/2014/09/30/police-raids-against-hungarian-ngos).

Waldner, David, dan Ellen Lust. 2018. "Unwelcome Change: Coming to Terms with Democratic Backsliding." Annual Review of Political Science 21(1):93-113. https://doi.org/10.1146/annurevpolisci-050517-114628

Yilmaz, Ihsan. 2021. Erdogan's Political Journey: From Victimised Muslim Democrat to Authoritarian, Islamist Populist. European Center for Populism Studies. https://www.populismstudies.org/ erdogans-political-journey-from-victimised-muslim-democratto-authoritarian-islamist-populist/

Y1lmaz, Gozde. 2016. "Europeanisation or De-Europeanisation? Media Freedom in Turkey (1999-2015)." South European Society and Politics 21(1):147-161. https://doi.org/10.1080/13608746.2016. 1148102 
